\title{
1 Relative contribution of non-structural protein 1 in dengue
}

\section{2 pathogenesis}

3

4 Running title: Role of NS1 in dengue pathogenesis

6 Authors: Pei Xuan Lee ${ }^{1,2}$, Donald Heng Rong Ting ${ }^{1,2}$, Clement Peng Hee Boey ${ }^{1,2}$, 7 Eunice Tze Xin Tan ${ }^{1,2}$, Janice Zuo Hui Chia ${ }^{1,2}$, Li Ching Ong ${ }^{1,2}$, Yen Leong Chua ${ }^{1}$, 8 Chanditha Hapuarachchi ${ }^{3}$, Lee Ching $\mathrm{Ng}^{3}$, Sylvie Alonso ${ }^{1,2^{*}}$

Affiliations:

$11{ }^{1}$ Department of Microbiology \& Immunology, Yong Loo Lin School of Medicine, 12 National University of Singapore, Singapore.

$13 \quad{ }^{2}$ Immunology Programme, Life Sciences Institute, National University of Singapore, 14 Singapore.

$15{ }^{3}$ Environmental Health Institute at National Environment Agency, Singapore.

17 *Correspondence: 28 Medical Drive, Life Sciences Institute, Immunology programme, 18 Singapore 117456. micas@nus.edu.sg; ORCID \#: 0000-0001-7044-414X. 


\section{Abstract}

2 Dengue is a major public health concern in the tropical and sub-tropical world with no

3 effective treatment. The controversial live attenuated virus vaccine Dengvaxia has

4 boosted the pursuit of sub-unit vaccine approaches, and the non-structural protein 1

5 (NS1) has recently emerged as a promising candidate. However, we found that NS1

6 immunization or passive transfer of NS1 antibodies failed to confer protection in

7 symptomatic dengue mouse models using two non mouse-adapted DENV2 strains from

8 the Cosmopolitan genotype that currently circulates in South-East Asia. Furthermore,

9 exogenous administration of purified NS1 did not worsen in vivo vascular leakage in

10 sub-lethally infected mice, thereby supporting that NS1 does not play a critical role in

11 the pathogenesis of these DENV2 strains. Virus chimerization approaches indicated

12 that the prME structural region, but not NS1, plays a critical role in driving in vivo

13 fitness and virulence of the virus, through induction of key pro-inflammatory cytokines.

14 This work highlights that the pathogenic role of NS1 is DENV strain-dependent, which

15 warrants re-evaluation of NS1 as a universal dengue vaccine candidate.

18 Keywords: Dengue; NS1; prME; vascular leakage. 


\section{Introduction}

2 Dengue virus (DENV) is a mosquito-borne virus responsible for an estimated 390

3 million annual infections in the tropical and sub-tropical world (Bhatt et al., 2013). The

4 virus exists as four antigenically distinct serotypes (DENV1-4). Infection with DENV

5 results in a wide spectrum of disease manifestations ranging from mild to life-

6 threatening conditions, the latter being characterized by vascular leakage with or

7 without hemorrhage development (World Health Organisation, 2009, Kyle and Harris,

8 2008). DENV serotype cross-reactive immunity has been proposed, and to a certain

9 extent demonstrated, to represent a risk for the development of severe dengue.

10 Specifically, pre-existing antibodies raised during a previous heterotypic DENV

11 infection that recognize the structural components of the virion could enhance DENV

12 uptake and facilitate its replication within Fc $\gamma$ R-bearing cells, leading to increased

13 disease severity, a phenomenon coined as antibody-dependent enhancement (ADE)

14 (Halstead et al., 2002, Halstead, 2003). There is currently no effective therapeutics or

15 vaccine against dengue, which mainly stems from our lack of understanding of dengue

16 pathogenesis associated with limited availability of relevant symptomatic animal

17 models (Yauch and Shresta, 2008, Chan et al., 2015). The only licensed vaccine

18 Dengvaxia®, which consists of chimeric live attenuated tetravalent DENV, not only

19 offers limited protective efficacy particularly towards DENV2 strains, but was also

20 found to predispose immunologically dengue naïve individuals to an increased risk of

21 developing severe disease (Capeding et al., 2014, Villar et al., 2015, Aguiar et al., 2016,

22 Halstead, 2017). This latter observation had led to the suspension of dengue vaccination

23 programmes in the Philippines (Fatima and Syed, 2018). Thus, safer and more effective

24 second-generation vaccines are urgently needed. In the wake of Dengvaxia ${ }^{\circledR}$ setback

25 and controversy, sub-unit vaccine candidates have regained some traction (Lam et al., 
1 2016). While the envelope (E) protein of DENV has been the most popular sub-unit

2 vaccine candidate, a number of studies have also proposed DENV non-structural

3 protein 1 (NS1) as a potential candidate (Schlesinger et al., 1987, Henchal et al., 1988,

4 Falgout et al., 1990, Beatty et al., 2015, Goncalves et al., 2015, Wan et al., 2014, Wan

5 et al., 2017, Lai et al., 2017). NS1 is a glycosylated non-structural protein (46-55kDa)

6 that homo-dimerizes after post-translational modification, becomes membrane-

7 associated and participates in RNA replication within membrane-bound replication

8 complexes. Soluble hexameric NS1 (sNS1) is made of three dimers and a central lipid

9 cargo, and is secreted into the extracellular milieu (Gutsche et al., 2011, Muller and

10 Young, 2013, Watterson et al., 2016). Cell surface-associated NS1 dimers and sNS1

11 hexamers are highly immunogenic (Muller and Young, 2013). sNS1 is detected in the

12 blood at concentration of up to $50 \mu \mathrm{g} / \mathrm{mL}$ and typically follows viremia in dengue

13 patients (Young et al., 2000, Libraty et al., 2002, Alcon et al., 2002), thus widely used

14 as an early diagnostic marker (Peeling et al., 2010, Hang et al., 2009, Chuansumrit et

15 al., 2011). Furthermore, recent studies have reported a role for sNS1 in dengue

16 pathogenesis, specifically in causing vascular leakage, a key clinical manifestation of

17 severe dengue (Beatty et al., 2015, Modhiran et al., 2015). As such, immunity raised

18 against NS1, either through direct immunization with purified sNS1 or via passive

19 transfer of anti-NS1 immune serum, was found to afford protection against lethal

20 DENV infection in a mouse model (Beatty et al., 2015). These findings thus support

21 that NS1 represents a promising sub-unit vaccine candidate and a safer alternative to

22 avoid the risk of ADE, which is a major roadblock in the development of vaccines that

23 rely on protective immunity against the structural components of DENV. However, the

24 role of NS1 in dengue pathogenesis and the in vivo protective efficacy of NS1 immunity

25 had been demonstrated in mouse models that either produce mild symptoms such as 
1 local skin hemorrhage and prolonged bleeding time (Wan et al., 2014, Wan et al., 2017,

2 Lai et al., 2017) or employ mouse-adapted DENV2 strains (Schlesinger et al., 1987,

3 Henchal et al., 1988, Falgout et al., 1990, Costa et al., 2006, Beatty et al., 2015).

4 Here, the role of NS1 in dengue pathogenesis as well as the protective potential of NS1

5 immunity were investigated in symptomatic dengue mouse models established with a

6 non mouse-adapted DENV2 strain, namely D2Y98P (Tan et al., 2010, Ng et al., 2014,

$7 \quad$ Martinez Gomez et al., 2016). In these models, neutralization of circulating sNS1

8 through antibody transfer or active NS1 immunization did not confer protection against

9 D2Y98P-induced disease, thus suggesting a limited role of sNS1 in the pathogenesis of

10 D2Y98P. Similar observations were made with a DENV2 clinical isolate that currently

11 circulates in Singapore and Malaysia. Instead, we showed that the prME region drives

12 the in vivo virulence of D2Y98P virus, through induction of key pro-inflammatory

13 cytokines. 


\section{Results}

\section{No protective efficacy of NS1 immunity in A129 and AG129 ADE mouse models}

3 The protective efficacy of NS1 was evaluated in symptomatic mouse models of dengue

4 that have been established with the non-mouse-adapted DENV2 D2Y98P strain (Tan

5 et al., 2010, Ng et al., 2014, Martinez Gomez et al., 2016). D2Y98P derives from a

61998 clinical isolate from the DENV2 Cosmopolitan genotype and has been exclusively

7 passaged for approximately 20 rounds in C6/36 mosquito cells (Tan et al., 2010). E

8 protein nucleotide sequence or the entire coding sequence of D2Y98P genome was

9 compared to that of a DENV2 prototype strain - NGC strain (Anez et al., 2016), and

10 with six other DENV2 Singapore isolates that were collected between 2007-2010 (Lee

11 et al., 2012). The results indicated 94\% identity with NGC and 98\% identity with the

12 six Singapore isolates, thus supporting that D2Y98P can be considered as a

13 representative of DENV2 strains that circulate in Singapore (Table S1).

14 Adult A129 mice (deficient in Type I interferon (IFN) pathway) were administered

15 thrice with commercially available purified hexameric NS1 from DENV2 strain 16681

16 according to a previously published immunization protocol (Beatty et al., 2015). High

17 titers of NS1-specific IgG antibodies were measured in the serum of the immunized

18 mice, with majority of the IgG1 subclass (Fig. S1). A control group consisting of mice

19 administered with ovalbumin (OVA) according to the same immunization regimen was

20 included. OVA- and NS1-immunized mice were then administered with DENV1-

21 immune serum one day prior to infection with D2Y98P strain in order to produce lethal

22 infection in an ADE setting (Fig. 1A).

23 NS1 (16681) and NS1 (D2Y98P) share 97\% amino acid identity and ability of the

24 immune serum raised against NS1(16681) to bind to and neutralize NS1(D2Y98P) was

25 verified by ELISA and sandwich ELISA, respectively (Fig. S1B and S1D). Consistently, 
1 significant reduction in circulating sNS1 was observed in NS1-immunized mice

2 compared to OVA-immunized animals after viral challenge (Fig. 1B), indicating that

3 NS1(16681) immunization successfully neutralized circulating sNS1 produced during

4 infection with D2Y98P virus. However, comparable viremia titers were measured

5 between NS1-immunized mice and OVA controls (Fig. 1C). Furthermore, NS1- and

6 OVA-immunized mice displayed similar disease manifestations and progression,

7 including hunched back, diarrhoea, lethargy, and eventually all the animals from both

8 groups were moribund by day 4 post-infection (p.i.) (Fig. 1D and E). Vascular leakage

9 in the liver and small intestines from NS1-immunized animals was as extensive as that

10 measured in the OVA control group (Fig. 1F). Systemic level of the liver enzyme AST

11 was also comparable between NS1- and OVA-immunized groups (Fig. 1G) and

12 massive cytoplasmic vacuolation was apparent in the hepatocytes from both infected

13 groups (Fig. 1H), indicating that reduction in sNS1 levels brought about by NS1

14 immunization did not protect the mice from DENV-induced severe liver damage

15 (Martinez Gomez et al., 2016).

16 Therefore, despite effective neutralization of circulating sNS1, active immunization

17 with purified NS1 failed to provide protection against lethal DENV2 challenge in an

18 A129 ADE model.

19 The protective potential of NS1 immunity was further explored in another lethal ADE 20 model using AG129 mice (deficient in Type I \& II IFN pathways) - a model in which 21 mice born to DENV1-immune dams exhibit extensive vascular leakage upon DENV2 22 infection (Ng et al., 2014). Since AG129 mice lack a functional IFN $\gamma$ signalling 23 pathway, direct immunization with purified NS1 may result in sub-optimal immune 24 responses that may affect the protective potential of NS1 immunity (van den Broek et 25 al., 1995). To address this possibility, NS1 immune serum was instead generated in 
1 A129 mice according to the same immunization protocol described above. One day

2 prior to DENV2 infection, AG129 mice born to DENV1-immune dams were then

3 passively transferred with the NS1 immune serum (Fig. 2A), which led to effective

4 neutralization of circulating sNS1 after D2Y98P challenge (Fig. 2B). However,

5 comparable viremia titers (Fig. 2C), survival rate (Fig. 2D), clinical symptoms (Fig. 2E)

6 and vascular leakage (Fig. 2F) were observed between mice administered with NS1

7 immune serum and the control group transferred with naïve serum.

8 Together, our data indicate that neither active NS1 immunization nor passive transfer

9 of NS1 immune serum conferred significant protection in both A129 and AG129 ADE

10 models, despite effective neutralization of circulating sNS1. These observations thus

11 imply that in these ADE infection models, sNS1 does not play a critical role in dengue 12 pathogenesis.

\section{Lack of protective NS1 immunity is independent of mouse background}

15 Previous studies that reported NS1-mediated protection were conducted in mouse 16 strains such as IFNAR ${ }^{-/-}$(Beatty et al., 2015) and STAT1 ${ }^{-/-}$(Wan et al., 2017, Lai et al., 2017), both being in the C57BL/6 background. We thus questioned whether the discrepancy between our observations and these earlier studies could be explained by a difference in mouse background. Hence, IFNAR ${ }^{-/}$mice of C56BL/6 background were immunized with NS1 or OVA according to the same immunization regimen as above,

21 followed by lethal challenge with D2Y98P (Fig. 3A). NS1-immunized IFNAR ${ }^{-/-}$mice 22 had significantly reduced sNS1 levels after D2Y98P challenge compared to OVA23 immunized controls, indicating effective neutralization of sNS1 in circulation (Fig. 3B).

24 However, comparable viremia titers (Fig. 3C), survival rates (Fig. 3D), weight loss 25 profiles (Fig. 3E) and vascular leakage (Fig. 3F) were measured between NS1- 
1 immunized and OVA control groups. These data thus indicate that the lack of protection

2 mediated by NS1-immunity is likely independent of the mouse background.

4 Lack of NS1-mediated protective efficacy was also observed with another circulating

5 DENV2 Singapore clinical isolate

6 While D2Y98P is not mouse-adapted, the virus had been passaged in C6/36 cell line

7 for several rounds, during which some mutations in the viral genome may have

8 modified the virus fitness. In particular, the presence of a phenylalanine (F) at position

952 in NS4B was found to play an important role in D2Y98P in vivo and in vitro fitness

10 (Grant et al., 2011, Tan et al., 2010). As none of the other DENV2 strains whose

11 genome sequence is available in the public database, harbors an $\mathrm{F}$ at this position, we

12 proposed that this particular amino acid was likely acquired during in vitro passages.

13 To examine whether the findings made with D2Y98P can be extended to other DENV2

14 strains, we have used another DENV2 clinical isolate, EHIE2862Y15, which has been

15 passaged in C6/36 cell line for no more than four rounds. This virus belongs to the

16 cosmopolitan genotype clade Ib that has been circulating in Singapore and Malaysia

17 since 2013 and has been associated with high fatality rate (Ng et al., 2015).

18 EHIE2862Y15 shares 98.6\% nucleotide identity and 99.6\% amino acid identity with

19 D2Y98P (Table S2). Interestingly, although EHIE2862Y15 does not harbor an F at

20 position 52 in NS4B, infection with EHIE2862Y15 gave rise to symptomatic infection

21 in AG129 mice, with a disease kinetic profile similar to that of D2Y98P (Fig. S2).

22 To evaluate the role of NS1 in the context of EHIE2862Y15 infection, IFNAR ${ }^{-/}$mice $^{-1}$

23 were immunized with purified NS1 followed by lethal viral challenge. Despite the

24 effective neutralization of circulating sNS1 (Fig. 4A), mice were not protected from

25 lethal EHIE2862Y15 challenge, as evidenced by comparable viremia titers (Fig. 4B), 
1 survival rates (Fig. 4C) and weight loss profile (Fig. 4D). Furthermore, significant

2 vascular leakage was measured in the liver and kidneys from NS1- and OVA-

3 immunized mice compared to uninfected controls, although the extent of vascular

4 leakage in the liver of NS1-immunized mice was slightly but significantly lower than

5 in OVA-immunized animals (Fig. 4E). Overall, these data support that the lack of NS1

6 immunity-mediated protection is not restricted to D2Y98P strain, but also applies to a

7 clinically relevant DENV2 isolate that is circulating in Singapore.

\section{$9 \quad$ Exogenous administration of sNS1 did not worsen dengue disease severity}

10 To assess the pathogenic role of sNS1 during D2Y98P infection, we tested whether the 11 exogenous administration of purified sNS1(D2Y98P) could aggravate disease severity in AG129 mice infected with a sub-lethal dose of D2Y98P (Fig. 5A). Administration of purified sNS1(D2Y98P) at day 2 p.i. led to significantly higher sNS1 level measured at day 4 p.i. compared to mice administered with OVA (Fig. 5B). No significant vascular leakage however was detected in any of the infected mice from both groups at this time point (Fig. 5C). Vascular leakage was also measured at day 6 p.i., when comparable levels of sNS1 were measured in both groups (Fig. 5B). It is likely that at this later time point, the sNS1 level mainly results from virus replication, and that exogenously added sNS1 had been cleared from the circulation and/or deposited onto the endothelial layer and internalized by endothelial cells. While no significant vascular

21 leakage was observed in the small intestine and spleen from both infected groups, liver 22 and kidneys did display significant vascular leak compared to uninfected controls (Fig.

23 5D). However, the extent of vascular leakage was not greater in mice administered with 24 exogenous sNS1 compared to the OVA control group (Fig. 5D). 
1 Since vascular leakage is more prominent at day 6 p.i. in this sub-lethal AG129 model,

2 we reasoned that delaying the exogenous administration of sNS1 from day 2 p.i. to day

34 p.i. may have a greater impact on vascular leakage. Significantly higher circulating

4 sNS1 levels were measured at day 6 p.i. in mice administered with purified sNS1 (Fig.

5 5E). However, these mice failed to exhibit greater vascular leakage than the OVA

6 control group (Fig. 5F). Viremia titers were also not enhanced with sNS1 administration

7 (Fig. S3).

8 Previous studies have reported the ability of sNS1 to activate toll-like receptor-4 (TLR4)

9 on immune cells leading to the production of vasoactive cytokines TNF- $\alpha$ (Modhiran 10 et al., 2015) and causing endothelial glycocalyx disruption (Puerta-Guardo et al., 2016).

11 However, D2Y98P-infected mice administered with exogenous sNS1 did not display 12 significantly higher levels of TNF- $\alpha$ compared to OVA controls (Fig. 5G). Likewise, 13 the levels of heparan sulphate in circulation, indicative of glycocalyx degradation, were 14 not enhanced with NS1 administration (Fig. 5H). These findings are consistent with the 15 observation that exogenous administration of sNS1 did not increase vascular leakage in 16 D2Y98P-infected mice.

\section{In vivo virulence of $\mathrm{D} 2 \mathrm{Y98P}$ is driven by structural prME region}

The data described above supported that NS1 does not play a critical role in the pathogenesis and in vivo fitness of the two DENV2 strains employed, and that other viral determinants are involved. The in vivo fitness of DENV was reported to be linked to its organ and cell tropism, which is mainly mediated by the prME structural region that harbors the receptor-binding site (Modis et al., 2004, Prestwood et al., 2008). To explore the mechanisms involved in D2Y98P fitness and virulence, we generated a chimeric virus where the prME region from D2Y98P was swapped with that of a 
1 DENV1 strain - 05K3903DK1, which typically gives rise to asymptomatic transient

2 viremia in AG129 mice (Fig. 6G). We also engineered another chimeric virus where

3 NS1 from D2Y98P was replaced by that of DENV1 (Fig. 6A and B).

4 Mice infected with DENV1-NS1-D2Y98P displayed a survival profile, clinical

5 manifestations and disease progression that were comparable to those seen with WT

6 D2Y98P virus (Fig. 6C, E). On the other hand, mice infected with DENV1-prME-

7 D2Y98P remained asymptomatic throughout the experiment, similar to WT DENV1

8 (Fig. 6D, F). Interestingly, the peak viremia titer (day 3 p.i.) in mice infected with

9 DENV1-prME-D2Y98P was similar to that measured in mice infected with DENV1-

10 NS1-D2Y98P (Fig. 6G), although the infection outcome induced by both viruses

11 differed drastically. Together, these observations support that prME, but not NS1,

12 drives D2Y98P virulence in mice. Swapping either NS1 or prME from DENV1 into

13 D2Y98P did impact significantly the viremia titers (Fig 6G), suggesting that these

14 proteins play a role in viral replication. The role of NS1 in DENV replication has indeed

15 been well established (Fan et al., 2014). Furthermore, a previous work has also reported

16 the existence of specific interactions between NS1 and prM/E that facilitate membrane

17 budding or conformational changes in the structural proteins necessary for formation

18 of nucleocapsids (Scaturro et al., 2015). This suggests that some compatibility between

19 both proteins is required for optimal viral replication. Consistently, when comparing

20 the kinetic profile in Vero cells of D2Y98P with that of DENV1-NS1-D2Y98P, a mild

21 but significant defect could be observed with the chimeric strain (Fig. 6H). In contrast,

22 the in vitro kinetic profile of DENV1-prME-D2Y98P was super-imposable to that of

23 WT D2Y98P (Fig. 6I). This latter observation thus implied that the lower viremia titers

24 measured in mice infected with DENV1-prME-D2Y98P cannot be explained by an

25 intrinsic defect in viral replication. 
1 To further understand the basis of the prME-driven virulence of D2Y98P, we examined

2 the cytokine profile in mice infected with the chimeric and WT strains (Fig 6J and S4).

3 Comparable high levels of key pro-inflammatory cytokines TNF- $\alpha$ and IL-6 were

4 measured in mice infected with DENV1-NS1-D2Y98P and WT D2Y98P (Fig. 6J). On

5 the other hand, mice infected with DENV1-prME-D2Y98P displayed significantly

6 reduced levels of these pro-inflammatory cytokines compared to D2Y98P-infected

7 mice, although higher than the levels measured in DENV1-infected animals (Fig. 6J).

8 Furthermore, DENV1-prME-D2Y98P was unable to suppress the production of anti-

9 inflammatory IL-10 (Fig. 6J).

10 Therefore, our data suggest that the in vivo virulence of D2Y98P virus is mainly driven

11 by its structural component - prME - through its ability to induce the production of key

12 pro-inflammatory cytokines. 


\section{Discussion}

2 The mechanisms that drive the fitness and virulence of DENV remain largely unknown

3 and are likely to be multifactorial. They include the ability to infect and replicate

4 effectively in various host cells as well as the ability to evade or counteract the host

5 defences (Mukhopadhyay et al., 2005, Hsieh et al., 2014, Hsieh et al., 2011, Munoz-

6 Jordan et al., 2003, Munoz-Jordan et al., 2005).

7 Beyond its role in DENV intracellular replication, recent literature has reported a

8 critical role of NS1 in dengue pathogenesis by interacting with the endothelium and

9 inducing vascular leakage, a clinical feature of severe dengue (Beatty et al., 2015,

10 Modhiran et al., 2015). Consequently, NS1 immunity was found to protect against

11 dengue disease (Beatty et al., 2015, Costa et al., 2006, Lai et al., 2017, Wan et al., 2014,

12 Wan et al., 2017). These in vivo studies were conducted with DENV clinical isolates or

13 mouse-adapted strains which either required very high dosage to induce lethality

14 (DENV2-454009A, D220, DENV2-3295) or induced only mild clinical symptoms

15 (DENV2-16681, DENV1-8700828, DENV3-8700829, DENV4-59201818, DENV2-

16 RJ) (Orozco et al., 2012, Beatty et al., 2015, Costa et al., 2006, Lai et al., 2017, Wan et

17 al., 2014, Wan et al., 2017, Chan et al., 2019), thus implying that the in vivo fitness of

18 these DENV strains is rather poor.

19 Here, we have used a non mouse-adapted DENV2 strain (D2Y98P) that is highly

20 virulent in mice (Tan et al., 2010, Ng et al., 2014, Martinez Gomez et al., 2016). In that

21 context, and using several symptomatic models in different mouse backgrounds, we did

22 not observe a role for circulating sNS1 in dengue pathogenesis. Neither could we see a

23 protective role for NS1 immunity. Similar observations were made with another

24 DENV2 clinical isolate that currently circulates in Singapore and Malaysia, and that is

25 equally virulent in mice. 
1 Consistently, the role of NS1 in human dengue disease has remained controversial. A

2 hospital-based study in dengue patients reported a positive association between

3 circulating sNS1 levels and dengue disease severity, and proposed that levels greater

4 than $600 \mathrm{ng} / \mathrm{mL}$ are predictive of severe dengue (Libraty et al., 2002). However, a closer

5 examination of the data revealed that the correlation was not absolute, where a

6 proportion of patients with self-limiting dengue fever displayed levels of sNS1 above

$7600 \mathrm{ng} / \mathrm{mL}$. Likewise, a subset of patients who developed severe dengue had sNS1

8 levels below the detectable range or considerably lower than $600 \mathrm{ng} / \mathrm{mL}$ (Libraty et al.,

9 2002). Furthermore, a more recent prospective study conducted in Vietnam found no

10 association between sNS1 level and severe dengue (Fox et al., 2011). As these patients

11 were likely to be infected with DENV from different serotypes and strains, the authors

12 suggested that the correlation between sNS1 levels and disease severity may be strain-

13 dependent. A separate prospective study indeed reported that the level of circulating

14 sNS1 produced in infected individuals differs greatly across DENV serotypes and even

15 among strains of the same DENV2 serotype (Duyen et al., 2011). Therefore, data from

16 dengue patient cohorts do not seem to support a strong correlation between the level of

17 circulating sNS1 and disease severity.

18 Currently, little is known about the viral determinants that influence DENV virulence

19 in humans. A number of studies have reported that some lineages seem to be more

20 virulent than others, based on their ability to replicate in their host and give high viremia

21 titers (Rico-Hesse et al., 1997, Leitmeyer et al., 1999, Armstrong and Rico-Hesse, 2001,

22 Cologna et al., 2005). DENV strains with greater replicative ability in their host are

23 thought to spread more rapidly and successfully than those with a lower fitness

24 (Guzman and Harris, 2015, Cologna et al., 2005). As a non-structural protein that plays

25 a critical role in viral replication, NS1 has been naturally proposed to be a key 
1 determinant in driving the fitness of DENV, and studies have shown that single amino

2 acid substitutions within NS1 could affect viral production and consequently disease

3 severity (Rodriguez-Roche et al., 2005, Rodriguez-Roche et al., 2011, Chan et al.,

4 2019). Other mechanisms have also been proposed and include the ability to evade,

5 deceive or interfere with the host defences, through production of sub-genomic viral

6 RNA (Finol and Ooi, 2019), immature viral particles (Rodenhuis-Zybert et al., 2010),

7 or specific interactions between viral and host proteins (Munoz-Jordan et al., 2003,

8 Munoz-Jordan et al., 2005).

9 Our data support that prME drives the in vivo virulence of D2Y98P. As prM and E form 10 the outer protein shell of the virion, these proteins have been found to play a critical 11 role in receptor binding and entry into the host cell, thereby driving virus tropism 12 (Mukhopadhyay et al., 2005, Hsieh et al., 2014, Hsieh et al., 2011). Specifically, the two N-linked glycans on E protein at positions 67 and 153 have been shown to be crucial for binding to DC-SIGN and mannose receptors (Pokidysheva et al., 2006, 15 Tassaneetrithep et al., 2003, Miller et al., 2008). Although both N-glycosylation sites 16 are conserved among DENV strains, the sugar composition and branching structure present at each site differ among serotypes and even among strains within the same serotype (Yap et al., 2017). The sugar composition at the surface of the viral particles is likely to impact binding efficacy of the virus to its lectin-type host receptors, thereby influencing cell and organ tropism. In addition to receptor binding, glycans on E protein 21 may also play an important role in shaping the host immune responses, through modulation of the lectin pathway of complement activation, and induction of pro-

23 inflammatory cytokines through C-type lectin domain family 5 member A (CLEC5A) 24 receptor activation (Chen et al., 2008). Using a chimerization approach, we showed that 25 swapping prME region from DENV1 into D2Y98P virus did not modify the in vitro 
1 viral replication rate but significantly impaired the induction of pro-inflammatory

2 cytokines in vivo, which resulted in asymptomatic disease. We have indeed previously

3 shown that pro-inflammatory cytokines, in particular $\mathrm{TNF} \alpha$, play a critical role in

4 D2Y98P-induced disease, whereby administration of anti-TNF $\alpha$ antibodies partially or

5 completely protected mice from succumbing to the infection (Ng et al., 2014, Martinez

6 Gomez et al., 2016). Whether the glycan structures on (DENV1)E protein differ from

7 those found on (D2Y98P)E and are responsible for the phenotype observed remains to

8 be determined experimentally and is beyond the scope of this study. It is however

9 interesting to note that the prME region from DENV2 Singapore clinical isolate -

10 EHIE2862Y15, shares 100\% amino acid identity with prME of D2Y98P.

11

12 In conclusion, our work supports that the pathogenic role of sNS1 and consequently the

13 protective efficacy of NS1 immunity are not seen in the context of infection with two

14 DENV2 strains that belong to the cosmopolitan genotype, and whose virulence relies

15 instead on their structural components. Hence, we propose that the pathogenic role of

16 sNS1 is likely to be DENV strain-dependent. Given the highly diverse and vast number

17 of DENV strains circulating in the population (Kyle and Harris, 2008, Lee et al., 2012,

18 Hapuarachchi et al., 2016), disease pathology in infected individuals could be driven

19 by different key viral determinants with sNS1 playing a major or minor role. Hence, it

20 is critical to re-evaluate the protective potential of NS1 vaccination against a variety of

21 circulating DENV strains in order to avoid repeating the Dengvaxia scenario. 


\section{Materials \& Methods}

\section{Ethics statement}

3 All the animal experiments were carried in accordance with the guidelines of the

4 National Advisory Committee for Laboratory Animal Research (NACLAR). Animal

5 facilities are licensed by the regulatory body Agri-Food and Veterinary Authority of

6 Singapore (AVA). The described animal experiments were approved by the

7 Institutional Animal Care and Use Committee (IACUC) from National University of

8 Singapore (NUS) under the protocol number R14-0992 and R16-0422.

\section{$9 \quad$ Cell lines and viruses}

C6/36 Aedes albopictus cell line (American Type Culture Collection (ATCC) \#CRL-

11 1660) was maintained in Leibotvitz's L-15 medium (GIBCO) supplemented with 10\%

12 fetal bovine serum (FBS) (GIBCO) at $28^{\circ} \mathrm{C}$. Baby hamster kidney-21 (BHK-21)

13 (ATCC \#CCL-10) cell line was maintained in RPMI-1640 medium (GIBCO)

14 supplemented with $10 \%$ FBS and cultured at $37{ }^{\circ} \mathrm{C}$ with $5 \% \mathrm{CO}_{2}$. African green

15 monkey kidney epithelial (Vero) (ATCC \#CCL-81) cell line was maintained in DMEM

16 medium (GIBCO) supplemented with $10 \%$ FBS and cultured at $37{ }^{\circ} \mathrm{C}$ with $5 \% \mathrm{CO}_{2}$.

17 Human dermal blood microvascular endothelial cells (HMVEC) (\#CC-2811) (Lonza)

18 were maintained in $\mathrm{EGM}^{\mathrm{TM}}-2 \mathrm{MV}$ BulletKit ${ }^{\mathrm{TM}}$ medium (Lonza) at $37^{\circ} \mathrm{C}$ with $5 \% \mathrm{CO}_{2}$.

19 DENV1 (Dengue 1 05K3903DK1) (GenBank accession number EU081242) was

20 isolated during the 2005 dengue outbreak in Singapore. DENV2 (Dengue D2Y98P)

21 (GenBank accession number JF327392) derives from a clinical strain isolated in

22 Singapore in 1998 that had been exclusively passaged in C6/36 cells and plaque purified

23 twice in BHK-21 cells. EHIE2862Y15 (GenBank accession number MK513444) was

24 a DENV2 clinical strain isolated in Singapore in 2015. All DENV stocks were 
1 propagated in C6/36 cell line maintained in Leibovitz's L-15 medium supplemented

2 with 2\% FBS as previously described (Ng et al., 2014). Harvested culture supernatants

3 containing the virus particles were stored at $-80{ }^{\circ} \mathrm{C}$. Virus titers were determined by

4 plaque assay in BHK-21 cells as described below.

\section{Virus quantification}

6 Virus titer was quantified by plaque assay in BHK-21 cells as previously described $(\mathrm{Ng}$ 7 et al., 2014). Briefly, 40,000 cells/well were seeded in 24-well plates (NUNC) one day

8 before plaque assay. Cell monolayers were then infected with 10 -fold serially diluted

9 viral suspensions in RPMI-1640 medium supplemented with 2\% FBS. After one hour 10 incubation at $37{ }^{\circ} \mathrm{C}$ with $\mathrm{CO}_{2}$, overlay medium (RPMI-1640 medium containing $1 \%$ 11 (w/v) carboxymethyl cellulose (CMC) and 2\% FBS) was added to each well. After incubation for four (DENV2) or five (DENV1) days at $37^{\circ} \mathrm{C}$ with $\mathrm{CO}_{2}$, cells were fixed with 4\% paraformaldehyde (Sigma-Aldrich) and stained with $0.05 \%$ crystal violet

14 (Sigma-Aldrich). Plaques were counted, adjusted by dilution and expressed as the 15 number of plaque forming unit per milliliter (PFU/mL).

\section{Chimeric virus construction and production}

17 Fragments from DENV2 (D2Y98P) and DENV1 (05K3903DK1) genomes were obtained by polymerase chain reaction (PCR) amplification or de novo synthesis. Primer sequences used for amplification are listed in Table S3. PCR was performed using Q5@ Hot Start high-fidelity DNA polymerase (New England Biolabs) according

21 to the manufacturer's instructions. All PCR products were purified from agarose gel using QIAquick ${ }^{\circledR}$ gel extraction kit (Qiagen) following the manufacturer’s instructions. using DNA assembly of PCR fragments by Gibson assembly technique as previously 25 described (Siridechadilok et al., 2013). The pACYC177 plasmid containing CMV 
1 promoter, HDV ribozyme and SV40 PA was a kind gift from Prof Ooi Eng Eong, Duke-

2 NUS. The vector and viral DNA fragments, were assembled together using Gibson

3 Assembly® Master Mix (New England Biolabs) at $50^{\circ} \mathrm{C}$ for two hours. The assembly

$4 \operatorname{mix}(15 \mu \mathrm{L})$ was then directly transfected into BHK-21 cells using Lipofectamine-

$5 \quad 2000 \AA$ transfection reagent (Thermo-Fisher) in Opti-MEM medium (Thermo-Fisher)

6 as described in the manufacturer's protocol. After incubation for four hours at $37{ }^{\circ} \mathrm{C}$

7 with $\mathrm{CO}_{2}$, the medium was changed to MEM medium (GIBCO) supplemented with

8 10\% FBS. Culture supernatants containing the virus were collected daily from day one

9 to day five post-transfection and the presence of virus was verified by plaque assay.

10 The chimeric viruses were eventually propagated in C6/36 cell line for two passages.

11 NS1 immunization and mouse infection

12 Five to six week-old A129 mice (129/Sv mice deficient in IFN- $\alpha / \beta$ receptors) were

13 immunized intraperitoneally (ip) thrice (week 0, 2 and 6) with $20 \mu \mathrm{g}$ of hexameric NS1

14 from DENV2 16681 strain (The Native Antigen Company) or OVA protein (InvivoGen)

15 adjuvanted with $1 \mu$ g of monophosphoryl lipid A (MPLA) (InvivoGen) and 1:1 volume

16 AddaVax (InvivoGen) as described previously (Beatty et al., 2015). Two weeks after

17 the last administration, A129 mice were challenged with $10^{6}$ PFU DENV2 (D2Y98P)

18 intravenously (iv) one day after iv administration of DENV1-immune serum to trigger

19 ADE.

20 Following the same NS1(16681) immunization regimen in A129 mice, NS1 immune

21 serum was collected two weeks after the third immunization and heat-inactivated at 56

$22{ }^{\circ} \mathrm{C}$ for 30 minutes before storage at $-80{ }^{\circ} \mathrm{C}$. Antibody titers of immune serum were

23 quantified by ELISA. The stored immune sera were subsequently used for passive

24 transfer experiment into AG129 mice (129/Sv mice deficient in IFN- $\alpha / \beta$ and IFN- $\gamma$

25 receptors) born to DENV1-immune mothers. One day post-administration of NS1 
1 immune serum (150 $\mu \mathrm{L}$ per mouse), these AG129 mice were subcutaneously (sc)

2 challenged with $10^{3}$ PFU of DENV2 (D2Y98P).

3 Five to seven week-old IFNAR $^{-/-}$mice (C57BL/6 deficient in interferon- $\alpha / \beta$ receptors)

4 were subjected to the same immunization regimen with NS1(16681) or OVA protein

5 as described above, and were challenged sc with $10^{5}$ PFU DENV2 (D2Y98P or

6 EHIE2862Y15) two weeks after the third immunization.

\section{$7 \quad$ Administration of NS1 protein}

8 Five to six weeks old AG129 mice were infected sc with $10^{3}$ PFU sub-lethal dose of

9 D2Y98P. Two or four days p.i., $10 \mathrm{mg} / \mathrm{kg}$ of purified NS1(D2Y98P) (The Native

10 Antigen Company) or OVA protein (InvivoGen) was administered iv to the infected

11 mice.

\section{Primary infection with chimeric viruses}

13 Five to six weeks old AG129 mice were sc infected with $10^{6} \mathrm{PFU}$ of parental (D2Y98P 14 or DENV1) or chimeric (DENV1-NS1-D2Y98P or DENV1-prME-D2Y98P) viruses.

\section{Quantification of vascular leakage}

Vascular leakage was assessed by Evans blue dye extravasation as previously described blue dye (Sigma-Aldrich) in PBS adjusted to the weight of mouse (10 $\mu \mathrm{L} /$ gram body weight). Two hours after administration, mice were euthanized and extensively perfused with PBS. Organs (liver, small intestines, spleen and kidneys) were harvested and weighed. Evans blue dye was extracted from the organs by the addition of N,Ndimethylformamide (Sigma-Aldrich) (adjusted to $4 \mathrm{~mL} / \mathrm{g}$ wet tissue) and incubated overnight at $37^{\circ} \mathrm{C}$. Extracted dye was read at $620 \mathrm{~nm}$, and data were expressed as absolute absorbance. 
1 Mice were sacrificed at the indicated time point and the liver was harvested and fixed

2 immediately with 4\% paraformaldehyde in PBS. Fixed tissues were processed for

3 embedding, sectioning and staining with Haematoxylin and Eosin (H\&E) (Department

4 of Pathology, NUS). Slides were viewed under microscope (Leica) and images were

5 captured.

\section{Enzyme-link immunosorbent assays}

7 Levels of systemic IgG antibodies specific to NS1 protein were quantified via indirect

8 enzyme-link immunosorbent assay (ELISA). Purified NS1 protein from D2Y98P or

916681 (10 ng/well) diluted in PBS was coated onto 96-well EIA plates (Corning costar)

10 overnight at $4{ }^{\circ} \mathrm{C}$. Plates were washed thrice with wash buffer $(0.05 \%$ Tween 20 in

11 PBS) and blocked with reagent diluent (2\% BSA in wash buffer) for one hour at $37{ }^{\circ} \mathrm{C}$.

12 Serially diluted serum samples were added to the wells and incubated at $37^{\circ} \mathrm{C}$. Plates

13 were washed thrice before the addition of horseradish peroxidase (HRP)-conjugated

14 anti-mouse IgG (H+L) (Bio-rad, 170-6516) at 1:3,000; anti-mouse IgG1, IgG2a and

15 IgG2b (abcam ab97240, ab97245, ab97250) at 1:10,000. Plates were incubated for one

16 hour at $37^{\circ} \mathrm{C}$. After the final three washes, detection was performed by the addition of o-phenylene-diamine dihydrochloride substrate SigmaFast (Sigma-Aldrich) and incubated for 30 minutes at room temperature. The reaction was stopped upon the addition of $2 \mathrm{~N} \mathrm{H}_{2} \mathrm{SO}_{4}$. Absorbance was read at $490 \mathrm{~nm}$, and antibody titer was determined by non-linear regression as the reciprocal of the highest serum dilution with

21 absorbance corresponding to three times the absorbance of blank wells.

22 Levels of systemic sNS1 in mice during the course of infection or NS1 in in vitro 23 experiment were quantified via sandwich ELISA as described previously (Watanabe et 24 al., 2012). Mouse anti-NS1 Mab62.1 (a kind gift from Prof Subhash Vasudevan, Duke25 NUS and Prof Christiane Ruedl, Nanyang Technological University) (0.1 $\mu \mathrm{g} / \mathrm{well})$ 
1 diluted in PBS was coated onto 96-well EIA plates overnight at $4{ }^{\circ} \mathrm{C}$. After washing

2 and blocking as described above, diluted serum samples (from 1:100 to 1:2,500) were

3 added to the wells and incubated for 2.5 hours at $37^{\circ} \mathrm{C}$. Standard curve was established

4 by two-fold serial dilution of recombinant NS1 (D2Y98P or 16681) from $25 \mathrm{ng} / \mathrm{mL}$ to

$5 \quad 0.39 \mathrm{ng} / \mathrm{mL}$. Plates were washed five times before the addition of HRP-conjugated

6 mouse anti-NS1 MAb56.2 (a kind gift from Prof Subhash Vasudevan, Duke-NUS and

7 Prof Christiane Ruedl, Nanyang Technological University) (25 ng/well, made by

8 conjugating $\mathrm{HRP}$ to MAb56.2 using $\mathrm{NH}_{2}$ peroxidase labelling kit (Abnova) and

9 incubated for 1.5 hours at room temperature. After the final washes, detection was

10 performed with the addition of tetramethylbenzidine (R\&D Systems) for 30 minutes at

11 room temperature. The reaction was stopped with $2 \mathrm{~N} \mathrm{H}_{2} \mathrm{SO}_{4}$. Absorbance was read at

$12450 \mathrm{~nm}$. The concentration of NS1 was calculated based on the standard curve and

13 expressed as the concentration of NS1 in $\mathrm{ng} / \mathrm{mL}$.

14 Levels of circulating TNF- $\alpha$ in infected mice were measured using Mouse TNF- $\alpha$

15 Immunoassay Quantikine ${ }^{\circledR}$ ELISA kit (R\&D Systems) according to the manufacturer’s

16 instructions. Levels of heparan sulphate in circulation were quantified using Mouse

17 Heparan Sulfate ELISA kit (G-Biosciences) according to the manufacturer's

18 instructions.

19 Multiplex cytokine and soluble mediators detection

20 Levels of cytokines and soluble mediators present in plasma of infected mice were 21 quantified using LEGENDplex ${ }^{\mathrm{TM}}$ Mouse Inflammatory Panel kit (Biolegend)

22 according to the manufacturer's protocol. Samples were run using Attune ${ }^{\mathrm{TM}} \mathrm{Nxt}$ flow 23 cytometer and analyzed using FlowJo software.

\section{$24 \quad$ In vitro DENV infection}


1 Vero cells were infected at a multiplicity of infection (MOI) of 0.1 with D2Y98P,

2 DENV1, DENV1-prME-D2Y98P and DENV1-NS1-D2Y98P. Plates were incubated at

$337^{\circ} \mathrm{C}$ for one hour with rocking every 15 minutes interval for viral adsorption. Each

4 well was rinsed twice with PBS before addition of $200 \mu \mathrm{L}$ of DMEM medium

5 containing 2\% FBS. The plates were incubated for four days and the culture supernatant

6 was collected at indicated time points post-infection. Viral quantification was

7 performed by plaque assay.

\section{Statistical analysis}

9 Data analyses were performed using Graphpad Prism 6.0. Statistical comparison was

10 conducted using non-parametric Mann-Whitney test or linear regression. Comparison

11 of survival rates was performed using Log-rank (Mantel-Cox) test. Differences were

12 considered significant $(*)$ at $p$ value $<0.05$. 


\section{Author Contributions}

2 PXL, DHRT, CLPHB, ETXT, JZHC, LCO, YLC, CH performed the experiments;

3 PXL, DHRT, SA designed the experiments and wrote the manuscript; PXL, DHRT,

$4 \quad \mathrm{CH}, \mathrm{LCN}, \mathrm{SA}$ analysed the data.

5

6 Acknowledgements

7 We thank Prof Subhash Vasudevan, Duke-NUS and Prof Christiane Ruedl, Nanyang

8 Technological University for the kind gift of mouse monoclonal anti-NS1 antibodies

9 for ELISA. We also thank Prof Ooi Eng Eong, Duke-NUS for sharing his pACYC177

10 plasmid construct for Gibson assembly work.

11 This work was funded by the Singapore Ministry of Health (CBRG13nv005 and

12 MOHIAFCAT2/3/011 awarded to SA).

13

\section{Declaration of Interests}

15 The authors declare no competing interests.

16 


\section{References}

AGUIAR, M., STOLLENWERK, N. \& HALSTEAD, S. B. 2016. The risks behind Dengvaxia recommendation. Lancet Infect Dis, 16, 882-3.

ALCON, S., TALARMIN, A., DEBRUYNE, M., FALCONAR, A., DEUBEL, V. \& FLAMAND, M. 2002. Enzyme-linked immunosorbent assay specific to Dengue virus type 1 nonstructural protein NS1 reveals circulation of the antigen in the blood during the acute phase of disease in patients experiencing primary or secondary infections. J Clin Microbiol, 40, 376-81.

ANEZ, G., HEISEY, D. A., VOLKOVA, E. \& RIOS, M. 2016. Complete Genome Sequences of Dengue Virus Type 1 to 4 Strains Used for the Development of CBER/FDA RNA Reference Reagents and WHO International Standard Candidates for Nucleic Acid Testing. Genome Announc, 4.

ARMSTRONG, P. M. \& RICO-HESSE, R. 2001. Differential susceptibility of Aedes aegypti to infection by the American and Southeast Asian genotypes of dengue type 2 virus. Vector Borne Zoonotic Dis, 1, 159-68.

BEATTY, P. R., PUERTA-GUARDO, H., KILLINGBECK, S. S., GLASNER, D. R., HOPKINS, K. \& HARRIS, E. 2015. Dengue virus NS1 triggers endothelial permeability and vascular leak that is prevented by NS1 vaccination. Sci Transl Med, 7, 304ra141.

BHATT, S., GETHING, P. W., BRADY, O. J., MESSINA, J. P., FARLOW, A. W., MOYES, C. L., DRAKE, J. M., BROWNSTEIN, J. S., HOEN, A. G., SANKOH, O., MYERS, M. F., GEORGE, D. B., JAENISCH, T., WINT, G. R., SIMMONS, C. P., SCOTT, T. W., FARRAR, J. J. \& HAY, S. I. 2013. The global distribution and burden of dengue. Nature, 496, 504-7.

CAPEDING, M. R., TRAN, N. H., HADINEGORO, S. R., ISMAIL, H. I., CHOTPITAYASUNONDH, T., CHUA, M. N., LUONG, C. Q., RUSMIL, K., WIRAWAN, D. N., NALLUSAMY, R., PITISUTTITHUM, P., THISYAKORN, U., YOON, I. K., VAN DER VLIET, D., LANGEVIN, E., LAOT, T., HUTAGALUNG, Y., FRAGO, C., BOAZ, M., WARTEL, T. A., TORNIEPORTH, N. G., SAVILLE, M., BOUCKENOOGHE, A. \& GROUP, C. Y. D. S. 2014. Clinical efficacy and safety of a novel tetravalent dengue vaccine in healthy children in Asia: a phase 3, randomised, observer-masked, placebo-controlled trial. Lancet, 384, 1358-65.

CHAN, K. W., WATANABE, S., KAVISHNA, R., ALONSO, S. \& VASUDEVAN, S. G. 2015. Animal models for studying dengue pathogenesis and therapy. Antiviral Res, 123, 5-14.

CHAN, K. W. K., WATANABE, S., JIN, J. Y., POMPON, J., TENG, D., ALONSO, S., VIJAYKRISHNA, D., HALSTEAD, S. B., MARZINEK, J. K., BOND, P. J., BURLA, B., TORTA, F., WENK, M. R., OOI, E. E. \& VASUDEVAN, S. G. 2019. A T164S mutation in the dengue virus NS1 protein is associated with greater disease severity in mice. Sci Transl Med, 11.

CHEN, S. T., LIN, Y. L., HUANG, M. T., WU, M. F., CHENG, S. C., LEI, H. Y., LEE, C. K., CHIOU, T. W., WONG, C. H. \& HSIEH, S. L. 2008. CLEC5A is critical for dengue-virus-induced lethal disease. Nature, 453, 672-6.

CHUANSUMRIT, A., CHAIYARATANA, W., TANGNARARATCHAKIT, K., YOKSAN, S., FLAMAND, M. \& SAKUNTABHAI, A. 2011. Dengue nonstructural protein 1 antigen in the urine as a rapid and convenient diagnostic test during the febrile stage in patients with dengue infection. Diagn Microbiol Infect Dis, 71, 467-9. 
COLOGNA, R., ARMSTRONG, P. M. \& RICO-HESSE, R. 2005. Selection for virulent dengue viruses occurs in humans and mosquitoes. $J$ Virol, 79, 853-9.

COSTA, S. M., PAES, M. V., BARRETO, D. F., PINHAO, A. T., BARTH, O. M., QUEIROZ, J. L., ARMOA, G. R., FREIRE, M. S. \& ALVES, A. M. 2006. Protection against dengue type 2 virus induced in mice immunized with a DNA plasmid encoding the non-structural 1 (NS1) gene fused to the tissue plasminogen activator signal sequence. Vaccine, 24, 195-205.

DUYEN, H. T., NGOC, T. V., HA DO, T., HANG, V. T., KIEU, N. T., YOUNG, P. R., FARRAR, J. J., SIMMONS, C. P., WOLBERS, M. \& WILLS, B. A. 2011. Kinetics of plasma viremia and soluble nonstructural protein 1 concentrations in dengue: differential effects according to serotype and immune status. $J$ Infect Dis, 203, 1292-300.

FALGOUT, B., BRAY, M., SCHLESINGER, J. J. \& LAI, C. J. 1990. Immunization of mice with recombinant vaccinia virus expressing authentic dengue virus nonstructural protein NS1 protects against lethal dengue virus encephalitis. $J$ Virol, 64, 4356-63.

FAN, J., LIU, Y. \& YUAN, Z. 2014. Critical role of Dengue Virus NS1 protein in viral replication. Virol Sin, 29, 162-9.

FATIMA, K. \& SYED, N. I. 2018. Dengvaxia controversy: impact on vaccine hesitancy. J Glob Health, 8, 010312.

FINOL, E. \& OOI, E. E. 2019. Evolution of Subgenomic RNA Shapes Dengue Virus Adaptation and Epidemiological Fitness. iScience, 16, 94-105.

FOX, A., LE, N. M., SIMMONS, C. P., WOLBERS, M., WERTHEIM, H. F., PHAM, T. K., TRAN, T. H., TRINH, T. M., NGUYEN, T. L., NGUYEN, V. T., NGUYEN, D. H., FARRAR, J., HORBY, P., TAYLOR, W. R. \& NGUYEN, V. K. 2011. Immunological and viral determinants of dengue severity in hospitalized adults in Ha Noi, Viet Nam. PLoS Negl Trop Dis, 5, e967.

GONCALVES, A. J., OLIVEIRA, E. R., COSTA, S. M., PAES, M. V., SILVA, J. F., AZEVEDO, A. S., MANTUANO-BARRADAS, M., NOGUEIRA, A. C., ALMEIDA, C. J. \& ALVES, A. M. 2015. Cooperation between CD4+ T Cells and Humoral Immunity Is Critical for Protection against Dengue Using a DNA Vaccine Based on the NS1 Antigen. PLoS Negl Trop Dis, 9, e0004277.

GRANT, D., TAN, G. K., QING, M., NG, J. K., YIP, A., ZOU, G., XIE, X., YUAN, Z., SCHREIBER, M. J., SCHUL, W., SHI, P. Y. \& ALONSO, S. 2011. A single amino acid in nonstructural protein NS4B confers virulence to dengue virus in AG129 mice through enhancement of viral RNA synthesis. $J$ Virol, 85, 777587.

GUTSCHE, I., COULIBALY, F., VOSS, J. E., SALMON, J., D'ALAYER, J., ERMONVAL, M., LARQUET, E., CHARNEAU, P., KREY, T., MEGRET, F., GUITTET, E., REY, F. A. \& FLAMAND, M. 2011. Secreted dengue virus nonstructural protein NS1 is an atypical barrel-shaped high-density lipoprotein. Proc Natl Acad Sci U S A, 108, 8003-8.

GUZMAN, M. G. \& HARRIS, E. 2015. Dengue. Lancet, 385, 453-65.

HALSTEAD, S. B. 2003. Neutralization and antibody-dependent enhancement of dengue viruses. Adv Virus Res, 60, 421-67.

HALSTEAD, S. B. 2017. Dengvaxia sensitizes seronegatives to vaccine enhanced disease regardless of age. Vaccine, 35, 6355-6358.

HALSTEAD, S. B., LAN, N. T., MYINT, T. T., SHWE, T. N., NISALAK, A., KALYANAROOJ, S., NIMMANNITYA, S., SOEGIJANTO, S., VAUGHN, 
D. W. \& ENDY, T. P. 2002. Dengue hemorrhagic fever in infants: research opportunities ignored. Emerg Infect Dis, 8, 1474-9.

HANG, V. T., NGUYET, N. M., TRUNG, D. T., TRICOU, V., YOKSAN, S., DUNG, N. M., VAN NGOC, T., HIEN, T. T., FARRAR, J., WILLS, B. \& SIMMONS, C. P. 2009. Diagnostic accuracy of NS1 ELISA and lateral flow rapid tests for dengue sensitivity, specificity and relationship to viraemia and antibody responses. PLoS Negl Trop Dis, 3, e360.

HAPUARACHCHI, H. C., KOO, C., RAJARETHINAM, J., CHONG, C. S., LIN, C., YAP, G., LIU, L., LAI, Y. L., OOI, P. L., CUTTER, J. \& NG, L. C. 2016. Epidemic resurgence of dengue fever in Singapore in 2013-2014: A virological and entomological perspective. BMC Infect Dis, 16, 300.

HENCHAL, E. A., HENCHAL, L. S. \& SCHLESINGER, J. J. 1988. Synergistic interactions of anti-NS1 monoclonal antibodies protect passively immunized mice from lethal challenge with dengue 2 virus. J Gen Virol, 69 ( Pt 8), 2101-7.

HSIEH, S. C., WU, Y. C., ZOU, G., NERURKAR, V. R., SHI, P. Y. \& WANG, W. K. 2014. Highly conserved residues in the helical domain of dengue virus type 1 precursor membrane protein are involved in assembly, precursor membrane (prM) protein cleavage, and entry. J Biol Chem, 289, 33149-60.

HSIEH, S. C., ZOU, G., TSAI, W. Y., QING, M., CHANG, G. J., SHI, P. Y. \& WANG, W. K. 2011. The C-terminal helical domain of dengue virus precursor membrane protein is involved in virus assembly and entry. Virology, 410, 17080.

KYLE, J. L. \& HARRIS, E. 2008. Global spread and persistence of dengue. Annu Rev Microbiol, 62, 71-92.

LAI, Y. C., CHUANG, Y. C., LIU, C. C., HO, T. S., LIN, Y. S., ANDERSON, R. \& YEH, T. M. 2017. Antibodies Against Modified NS1 Wing Domain Peptide Protect Against Dengue Virus Infection. Sci Rep, 7, 6975.

LAM, J. H., ONG, L. C. \& ALONSO, S. 2016. Key concepts, strategies, and challenges in dengue vaccine development: an opportunity for sub-unit candidates? Expert Rev Vaccines, 15, 483-95.

LEE, K. S., LO, S., TAN, S. S., CHUA, R., TAN, L. K., XU, H. \& NG, L. C. 2012. Dengue virus surveillance in Singapore reveals high viral diversity through multiple introductions and in situ evolution. Infect Genet Evol, 12, 77-85.

LEITMEYER, K. C., VAUGHN, D. W., WATTS, D. M., SALAS, R., VILLALOBOS, I., DE, C., RAMOS, C. \& RICO-HESSE, R. 1999. Dengue virus structural differences that correlate with pathogenesis. J Virol, 73, 4738-47.

LIBRATY, D. H., YOUNG, P. R., PICKERING, D., ENDY, T. P., KALAYANAROOJ, S., GREEN, S., VAUGHN, D. W., NISALAK, A., ENNIS, F. A. \& ROTHMAN, A. L. 2002. High circulating levels of the dengue virus nonstructural protein NS1 early in dengue illness correlate with the development of dengue hemorrhagic fever. J Infect Dis, 186, 1165-8.

MARTINEZ GOMEZ, J. M., ONG, L. C., LAM, J. H., BINTE AMAN, S. A., LIBAU, E. A., LEE, P. X., ST JOHN, A. L. \& ALONSO, S. 2016. Maternal AntibodyMediated Disease Enhancement in Type I Interferon-Deficient Mice Leads to Lethal Disease Associated with Liver Damage. PLoS Negl Trop Dis, 10, e0004536.

MILLER, J. L., DE WET, B. J., MARTINEZ-POMARES, L., RADCLIFFE, C. M., DWEK, R. A., RUDD, P. M. \& GORDON, S. 2008. The mannose receptor mediates dengue virus infection of macrophages. PLoS Pathog, 4, e17. 
MODHIRAN, N., WATTERSON, D., MULLER, D. A., PANETTA, A. K., SESTER, D. P., LIU, L., HUME, D. A., STACEY, K. J. \& YOUNG, P. R. 2015. Dengue virus NS1 protein activates cells via Toll-like receptor 4 and disrupts endothelial cell monolayer integrity. Sci Transl Med, 7, 304ra142.

MODIS, Y., OGATA, S., CLEMENTS, D. \& HARRISON, S. C. 2004. Structure of the dengue virus envelope protein after membrane fusion. Nature, 427, 313-9.

MUKHOPADHYAY, S., KUHN, R. J. \& ROSSMANN, M. G. 2005. A structural perspective of the flavivirus life cycle. Nat Rev Microbiol, 3, 13-22.

MULLER, D. A. \& YOUNG, P. R. 2013. The flavivirus NS1 protein: molecular and structural biology, immunology, role in pathogenesis and application as a diagnostic biomarker. Antiviral Res, 98, 192-208.

MUNOZ-JORDAN, J. L., LAURENT-ROLLE, M., ASHOUR, J., MARTINEZSOBRIDO, L., ASHOK, M., LIPKIN, W. I. \& GARCIA-SASTRE, A. 2005. Inhibition of alpha/beta interferon signaling by the NS4B protein of flaviviruses. $J$ Virol, 79, 8004-13.

MUNOZ-JORDAN, J. L., SANCHEZ-BURGOS, G. G., LAURENT-ROLLE, M. \& GARCIA-SASTRE, A. 2003. Inhibition of interferon signaling by dengue virus. Proc Natl Acad Sci U S A, 100, 14333-8.

NG, J. K., ZHANG, S. L., TAN, H. C., YAN, B., MARTINEZ, J. M., TAN, W. Y., LAM, J. H., TAN, G. K., OOI, E. E. \& ALONSO, S. 2014. First experimental in vivo model of enhanced dengue disease severity through maternally acquired heterotypic dengue antibodies. PLoS Pathog, 10, e1004031.

NG, L. C., CHEM, Y. K., KOO, C., MUDIN, R. N., AMIN, F. M., LEE, K. S. \& KHEONG, C. C. 2015. 2013 dengue outbreaks in Singapore and Malaysia caused by different viral strains. Am J Trop Med Hyg, 92, 1150-5.

OROZCO, S., SCHMID, M. A., PARAMESWARAN, P., LACHICA, R., HENN, M. R., BEATTY, R. \& HARRIS, E. 2012. Characterization of a model of lethal dengue virus 2 infection in C57BL/6 mice deficient in the alpha/beta interferon receptor. J Gen Virol, 93, 2152-7.

PEELING, R. W., ARTSOB, H., PELEGRINO, J. L., BUCHY, P., CARDOSA, M. J., DEVI, S., ENRIA, D. A., FARRAR, J., GUBLER, D. J., GUZMAN, M. G., HALSTEAD, S. B., HUNSPERGER, E., KLIKS, S., MARGOLIS, H. S., NATHANSON, C. M., NGUYEN, V. C., RIZZO, N., VAZQUEZ, S. \& YOKSAN, S. 2010. Evaluation of diagnostic tests: dengue. Nat Rev Microbiol, 8, S30-8.

POKIDYSHEVA, E., ZHANG, Y., BATTISTI, A. J., BATOR-KELLY, C. M., CHIPMAN, P. R., XIAO, C., GREGORIO, G. G., HENDRICKSON, W. A., KUHN, R. J. \& ROSSMANN, M. G. 2006. Cryo-EM reconstruction of dengue virus in complex with the carbohydrate recognition domain of DC-SIGN. Cell, 124, 485-93.

PRESTWOOD, T. R., PRIGOZHIN, D. M., SHARAR, K. L., ZELLWEGER, R. M. \& SHRESTA, S. 2008. A mouse-passaged dengue virus strain with reduced affinity for heparan sulfate causes severe disease in mice by establishing increased systemic viral loads. J Virol, 82, 8411-21.

PUERTA-GUARDO, H., GLASNER, D. R. \& HARRIS, E. 2016. Dengue Virus NS1 Disrupts the Endothelial Glycocalyx, Leading to Hyperpermeability. PLoS Pathog, 12, e1005738.

RICO-HESSE, R., HARRISON, L. M., SALAS, R. A., TOVAR, D., NISALAK, A., RAMOS, C., BOSHELL, J., DE MESA, M. T., NOGUEIRA, R. M. \& DA 
ROSA, A. T. 1997. Origins of dengue type 2 viruses associated with increased pathogenicity in the Americas. Virology, 230, 244-51.

RODENHUIS-ZYBERT, I. A., VAN DER SCHAAR, H. M., DA SILVA VOORHAM, J. M., VAN DER ENDE-METSELAAR, H., LEI, H. Y., WILSCHUT, J. \& SMIT, J. M. 2010. Immature dengue virus: a veiled pathogen? PLoS Pathog, 6, e1000718.

RODRIGUEZ-ROCHE, R., ALVAREZ, M., GRITSUN, T., HALSTEAD, S., KOURI, G., GOULD, E. A. \& GUZMAN, M. G. 2005. Virus evolution during a severe dengue epidemic in Cuba, 1997. Virology, 334, 154-9.

RODRIGUEZ-ROCHE, R., SANCHEZ, L., BURGHER, Y., ROSARIO, D., ALVAREZ, M., KOURI, G., HALSTEAD, S. B., GOULD, E. A. \& GUZMAN, M. G. 2011. Virus role during intraepidemic increase in dengue disease severity. Vector Borne Zoonotic Dis, 11, 675-81.

SCATURRO, P., CORTESE, M., CHATEL-CHAIX, L., FISCHL, W. \& BARTENSCHLAGER, R. 2015. Dengue Virus Non-structural Protein 1 Modulates Infectious Particle Production via Interaction with the Structural Proteins. PLoS Pathog, 11, e1005277.

SCHLESINGER, J. J., BRANDRISS, M. W. \& WALSH, E. E. 1987. Protection of mice against dengue 2 virus encephalitis by immunization with the dengue 2 virus non-structural glycoprotein NS1. J Gen Virol, 68 ( Pt 3), 853-7.

SIRIDECHADILOK, B., GOMUTSUKHAVADEE, M., SAWAENGPOL, T., SANGIAMBUT, S., PUTTIKHUNT, C., CHIN-INMANU, K., SURIYAPHOL, P., MALASIT, P., SCREATON, G. \& MONGKOLSAPAYA, J. 2013. A simplified positive-sense-RNA virus construction approach that enhances analysis throughput. $J$ Virol, 87, 12667-74.

TAN, G. K., NG, J. K., TRASTI, S. L., SCHUL, W., YIP, G. \& ALONSO, S. 2010. A non mouse-adapted dengue virus strain as a new model of severe dengue infection in AG129 mice. PLoS Negl Trop Dis, 4, e672.

TASSANEETRITHEP, B., BURGESS, T. H., GRANELLI-PIPERNO, A., TRUMPFHELLER, C., FINKE, J., SUN, W., ELLER, M. A., PATTANAPANYASAT, K., SARASOMBATH, S., BIRX, D. L., STEINMAN, R. M., SCHLESINGER, S. \& MAROVICH, M. A. 2003. DCSIGN (CD209) mediates dengue virus infection of human dendritic cells. J Exp Med, 197, 823-9.

VAN DEN BROEK, M. F., MULlER, U., HUANG, S., AGUET, M. \& ZINKERNAGEL, R. M. 1995. Antiviral defense in mice lacking both alpha/beta and gamma interferon receptors. $J$ Virol, 69, 4792-6.

VILLAR, L., DAYAN, G. H., ARREDONDO-GARCIA, J. L., RIVERA, D. M., CUNHA, R., DESEDA, C., REYNALES, H., COSTA, M. S., MORALESRAMIREZ, J. O., CARRASQUILLA, G., REY, L. C., DIETZE, R., LUZ, K., RIVAS, E., MIRANDA MONTOYA, M. C., CORTES SUPELANO, M., ZAMBRANO, B., LANGEVIN, E., BOAZ, M., TORNIEPORTH, N., SAVILLE, M., NORIEGA, F. \& GROUP, C. Y. D. S. 2015. Efficacy of a tetravalent dengue vaccine in children in Latin America. N Engl J Med, 372, 113-23.

WAN, S. W., CHEN, P. W., CHEN, C. Y., LAI, Y. C., CHU, Y. T., HUNG, C. Y., LEE, H., WU, H. F., CHUANG, Y. C., LIN, J., CHANG, C. P., WANG, S., LIU, C. C., HO, T. S., LIN, C. F., LEE, C. K., WU-HSIEH, B. A., ANDERSON, R., YEH, T. M. \& LIN, Y. S. 2017. Therapeutic Effects of Monoclonal 
Antibody against Dengue Virus NS1 in a STAT1 Knockout Mouse Model of Dengue Infection. J Immunol, 199, 2834-2844.

WAN, S. W., LU, Y. T., HUANG, C. H., LIN, C. F., ANDERSON, R., LIU, H. S., YEH, T. M., YEN, Y. T., WU-HSIEH, B. A. \& LIN, Y. S. 2014. Protection against dengue virus infection in mice by administration of antibodies against modified nonstructural protein 1. PLoS One, 9, e92495.

WATTERSON, D., MODHIRAN, N. \& YOUNG, P. R. 2016. The many faces of the flavivirus NS1 protein offer a multitude of options for inhibitor design. Antiviral Res, 130, 7-18.

WORLD HEALTH ORGANISATION 2009. Dengue: guidelines for diagnosis, treatment, prevention and control.

YAP, S. S. L., NGUYEN-KHUONG, T., RUDD, P. M. \& ALONSO, S. 2017. Dengue Virus Glycosylation: What Do We Know? Front Microbiol, 8, 1415.

YAUCH, L. E. \& SHRESTA, S. 2008. Mouse models of dengue virus infection and disease. Antiviral Res, 80, 87-93.

YOUNG, P. R., HILDITCH, P. A., BLETCHLY, C. \& HALLORAN, W. 2000. An antigen capture enzyme-linked immunosorbent assay reveals high levels of the dengue virus protein NS1 in the sera of infected patients. J Clin Microbiol, 38, 1053-7. 
A

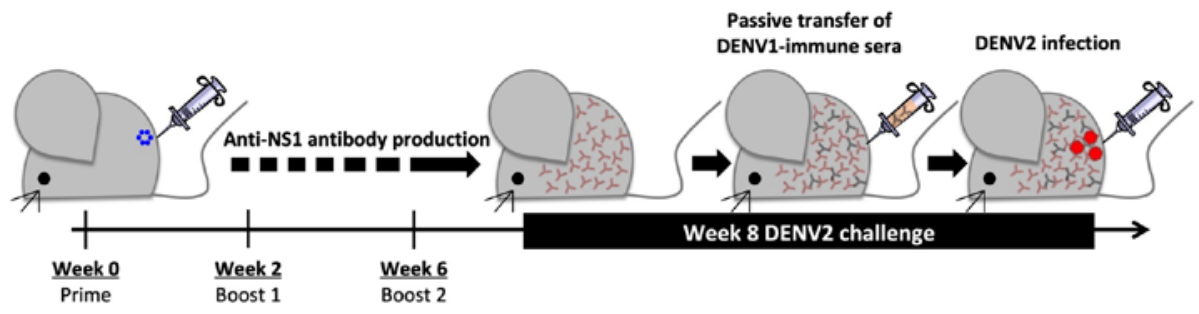

B

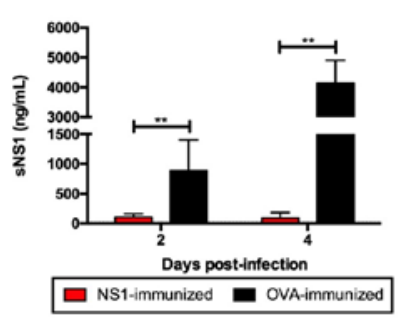

D

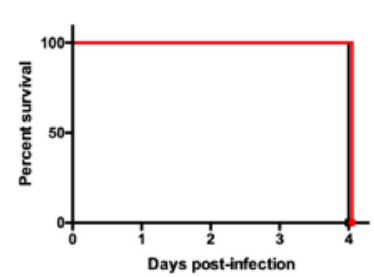

$\rightarrow$ NS1-immunized $\rightarrow$ OVA-immunized

$\mathbf{F}$

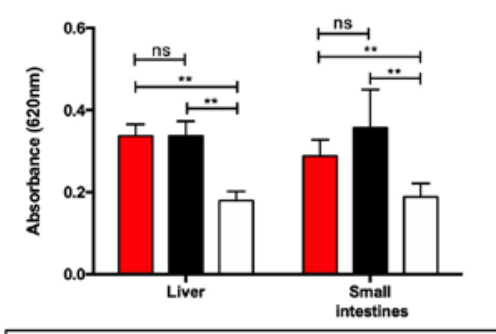

$\square$ NS1-immunized OVA-immunized $\square$ Uninfected

G

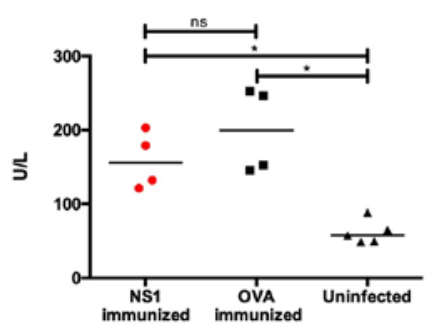

C

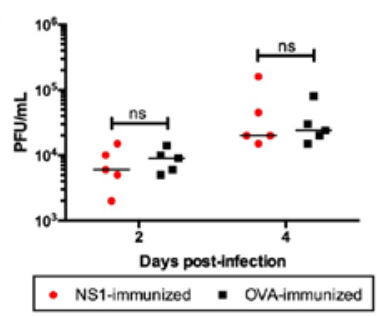

E

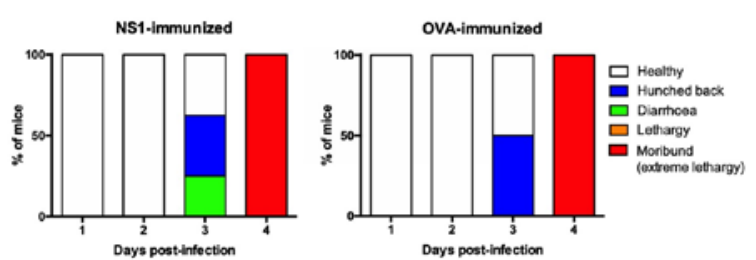

H
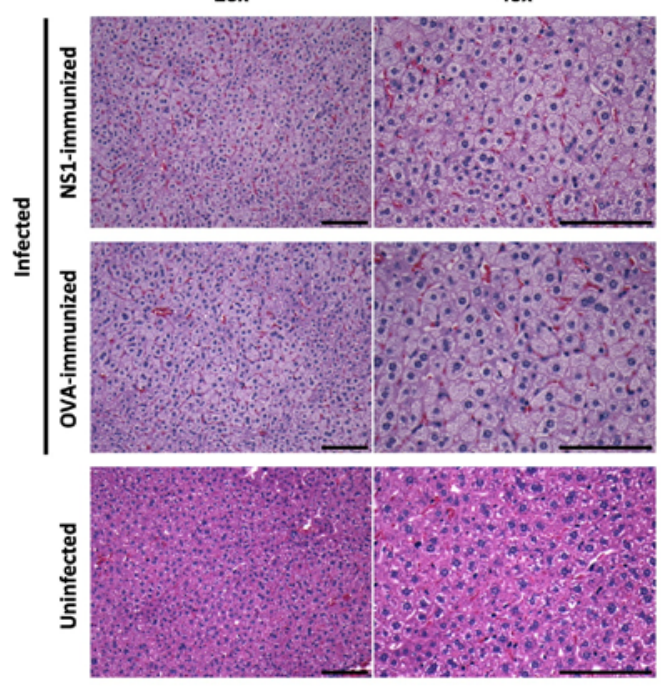

Fig. 1. NS1 immunization in A129 ADE infection model. (A) A129 mice were immunized (ip.) thrice with $20 \mu \mathrm{g}$ NS1(16681) or OVA adjuvanted with MPLA and Addavax. Eight weeks post-immunization, mice were passively transferred with DENV1-immune serum one day before iv challenge with $10^{6}$ PFU DENV2 (D2Y98P). (B) Circulating sNS1 levels and (C) viremia titers were measured $(n=5)$ at day 2 and 4 p.i. $(D, E)$ Mice $(n=8)$ were monitored daily upon challenge. The Kaplan-Meier survival curve and clinical scores are shown. (F) Vascular leakage was quantified by Evans blue dye extravasation assay in liver and small intestines at day 4 p.i. $(n=5)$. $(G)$ Systemic AST levels were measured $(n=4-5)$ and $(H)$ histological analysis of liver was performed at day 4 p.i. $(n=4-5)$. Images were taken at $20 x$ and 40x magnification. Representative sections are shown. (Scale bar - $10 \mu \mathrm{m}$ ). Data were analyzed by non-parametric Mann Whitney test. ${ }^{*} p<0.05$; ${ }^{* *} p<0.01$; ns: not significant. 
A

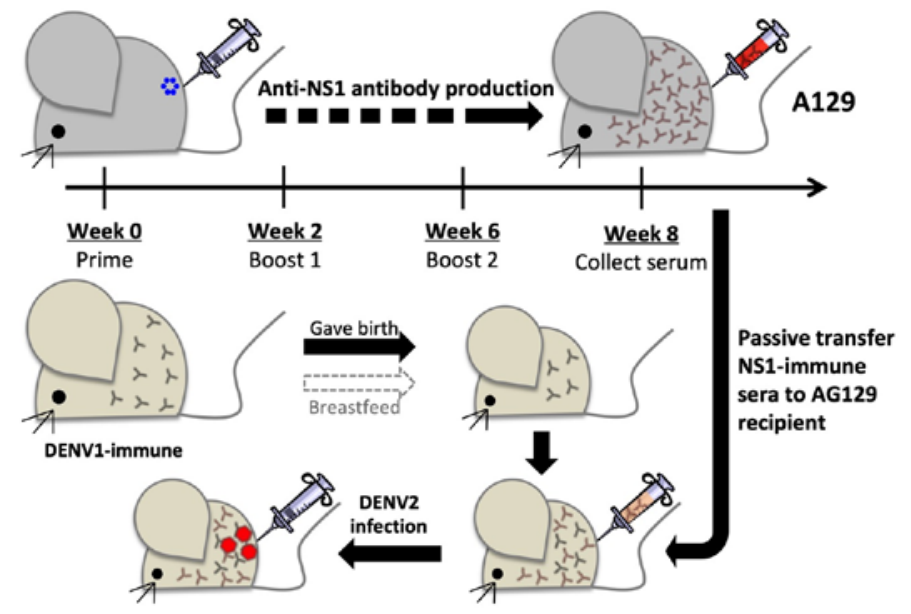

B

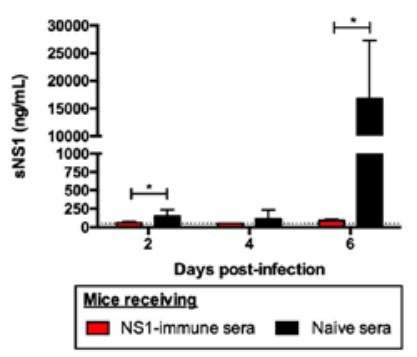

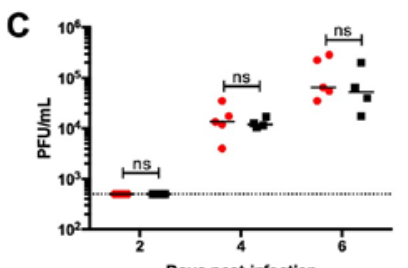

\section{Mice recelving}

- NS1-immune sera - Naive sera
D

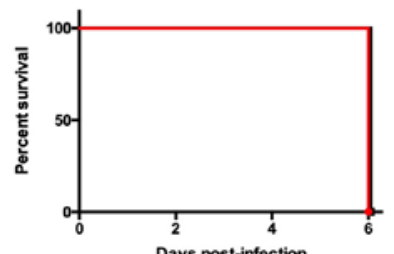

Mice receiving

$\rightarrow$ NS1-immune sera - Naive sera
E

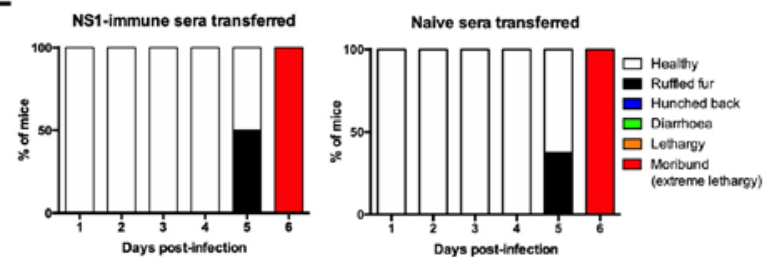

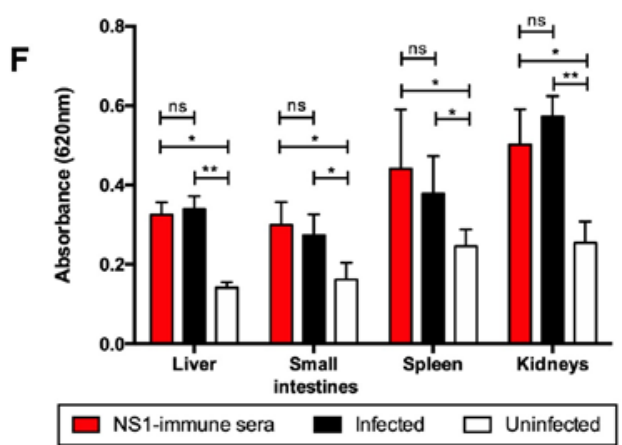

Fig. 2. Passive NS1 immunity in AG129 ADE infection model. (A) AG129 mice born to DENV1-immune mothers were passively transferred with NS1 immune serum collected from NS1(16681)-immunized A129 mice (Fig. 1A) or with naïve serum. One day after transfer, the mice were sc challenged with $10^{3}$ PFU D2Y98P. (B) Systemic sNS1 levels and (C) viremia titers were measured at day 2, 4 and 6 p.i. $(n=4-5)$. $(D$, E) Mice $(n=8)$ were monitored daily upon challenge. The Kaplan-Meier survival curve and clinical score were shown. (F) Vascular leakage was assessed in indicated tissues at day 6 p.i. $(n=4-5)$. Data were analyzed by nonparametric Mann Whitney test. ${ }^{*} p<0.05$; ${ }^{* *} p<0.01$; ns: not significant. 


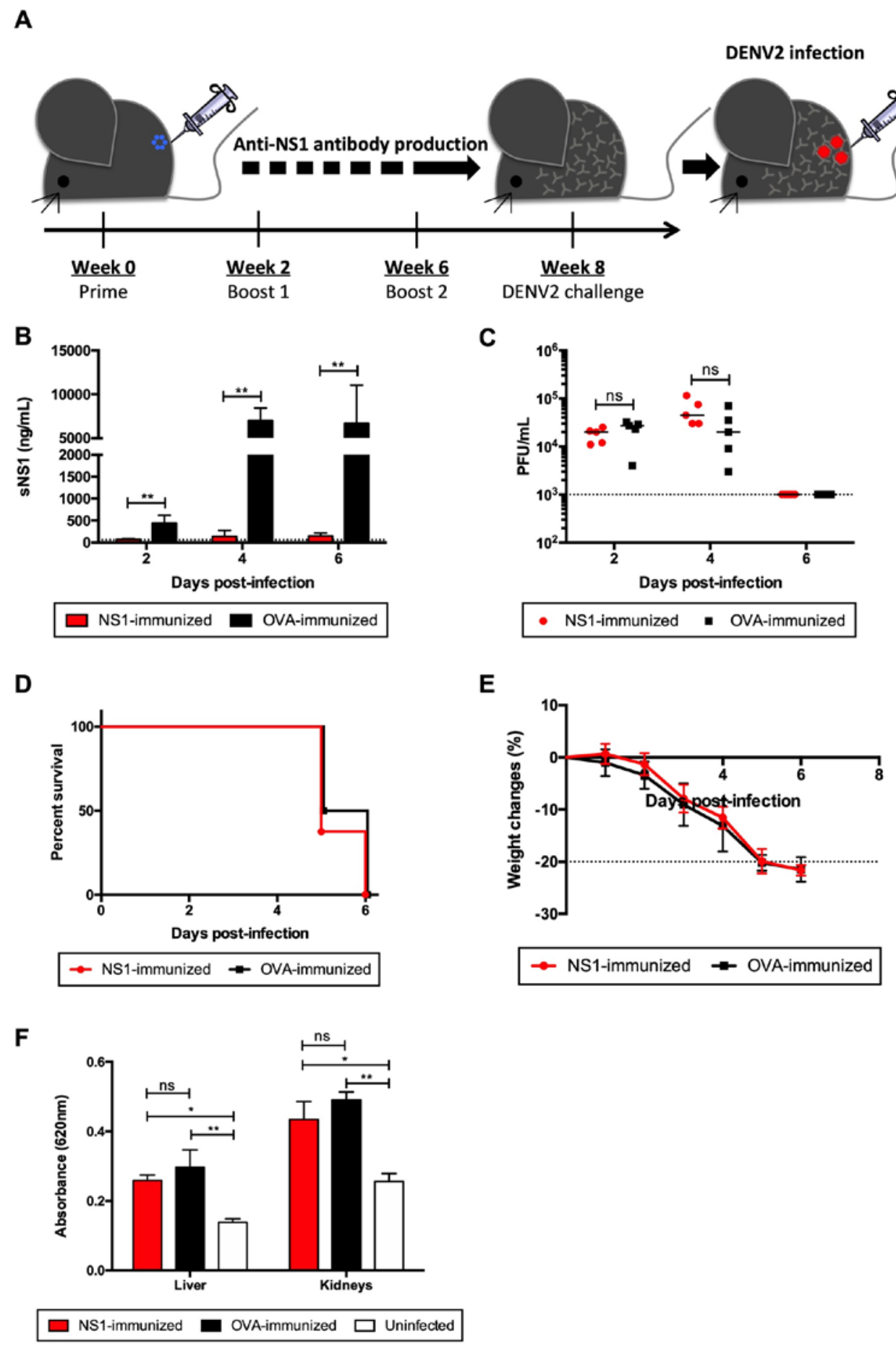

Fig. 3. NS1 immunization in IFNAR ${ }^{-/-}$primary infection model. (A) IFNAR ${ }^{-/}$mice were immunized with NS1(16681) or OVA as described in the legend of Fig. 1. Eight weeks postimmunization, mice were sc challenged with $10^{5}$ PFU D2Y98P. (B) Systemic sNS1 levels and (C) viremia titers were measured at day 2, 4 and 6 p.i. $(n=5)$. $(D, E)$ Mice $(n=6-8)$ were monitored daily upon challenge. The Kaplan-Meier survival curve and weight loss profile are shown. (F) Vascular leakage was assessed in liver and kidneys at day 4 p.i. $(n=4-5)$. Data were analyzed by non-parametric Mann Whitney test. ${ }^{*} p<0.05$; ${ }^{* *} p<0.01$; ns: not significant. 


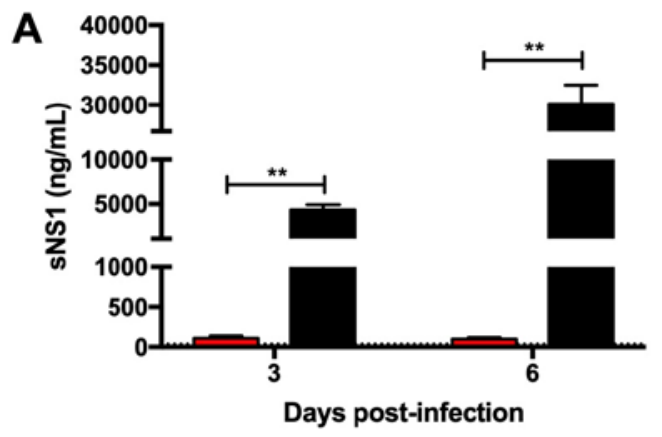

NS1-immunized

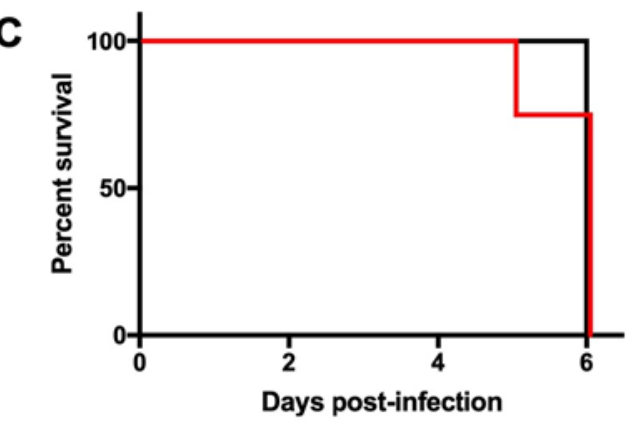

NS1-immunized
OVA-immunized

OVA-immunized
B

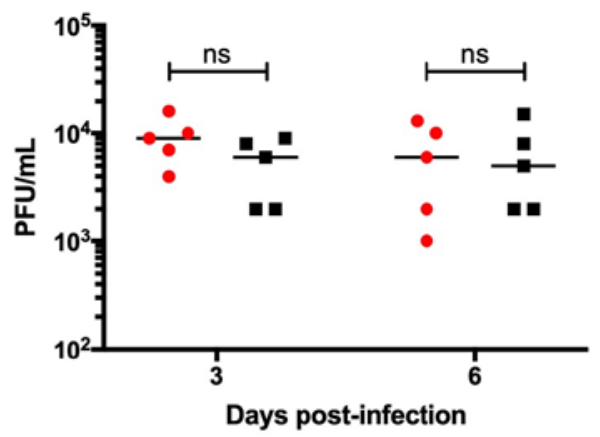

- NS1-immunized @ OVA-immunized

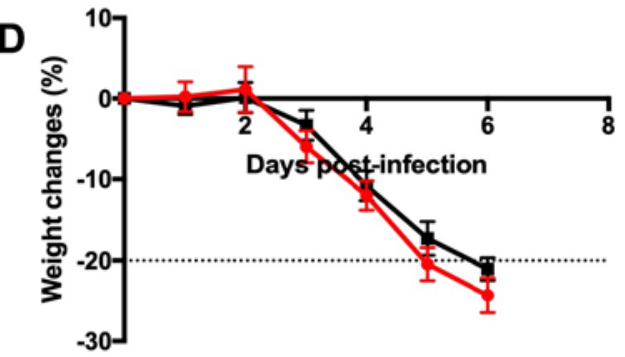

NS1-immunized OVA-immunized

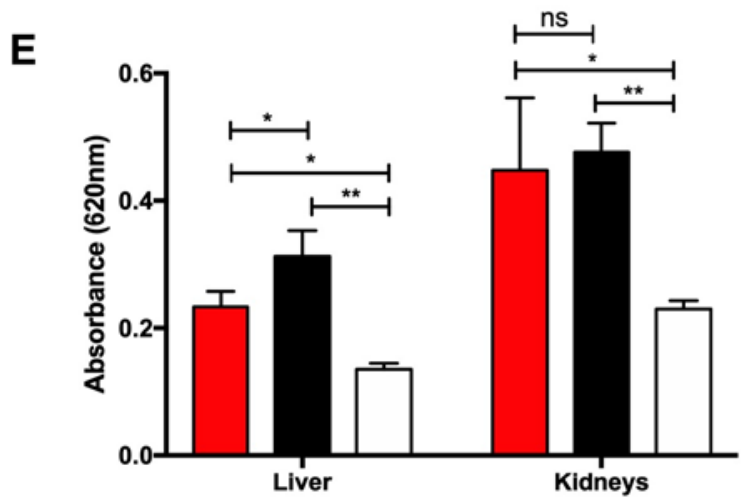

NS1-immunized

OVA-immunized

Uninfected

Fig. 4. Protective efficacy of NS1 immunity against a low-passaged DENV2 clinical isolate. IFNAR $^{-/}$mice were immunized with NS1(16681) or OVA as described in the legend of Fig 1. Eight weeks post-immunization, mice were sc challenged with $10^{5}$ PFU EHIE2862Y15. (A) Systemic sNS1 levels and (B) viremia titers were measured at day 3 and 6 p.i. $(n=5)$. (C, D) Mice $(n=8)$ were monitored daily upon challenge. The Kaplan-Meier survival curve and weight loss profile are shown. (E) Vascular leakage was assessed in the liver and kidneys at day 4 p.i. $(n=4-5)$. Data were analyzed by non-parametric Mann Whitney test. ${ }^{*} p<0.05$; $* * p<0.01$; ns: not significant. 
A

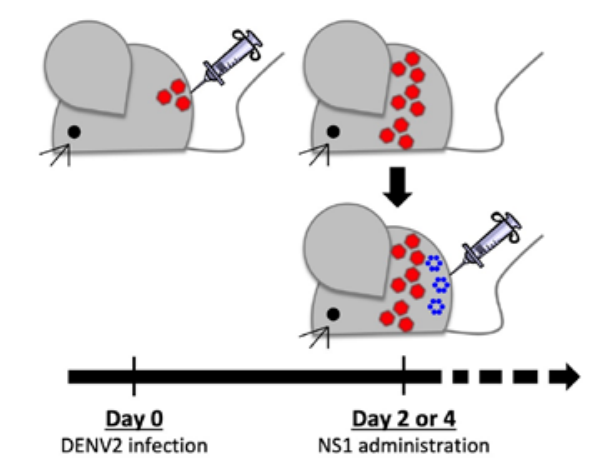

B

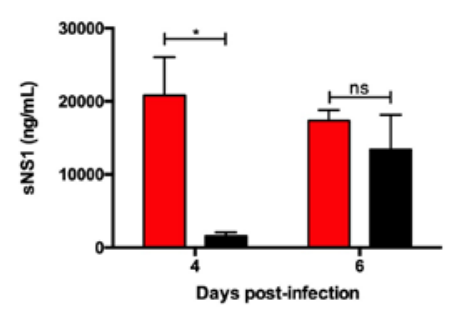

$\square$ NS1 administered OVA administered
C
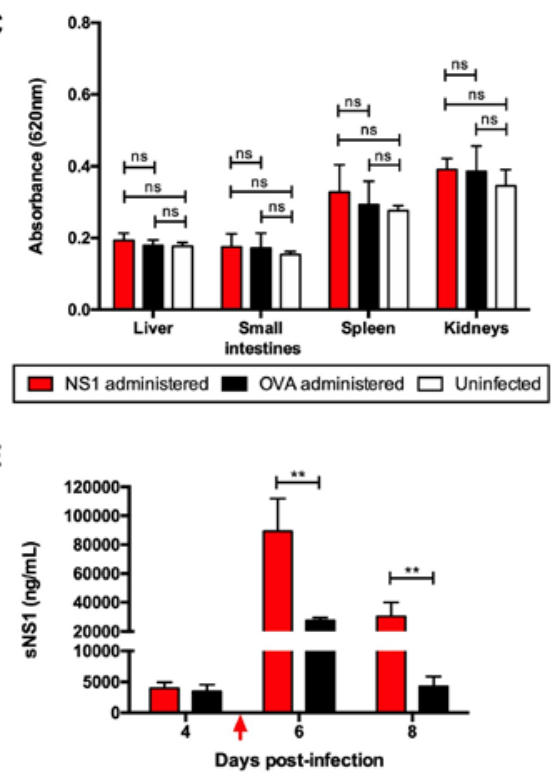

$\square$ NS1-administered $\square$ OVA-administered

$\uparrow$ Protein administered at day 4 post-infection

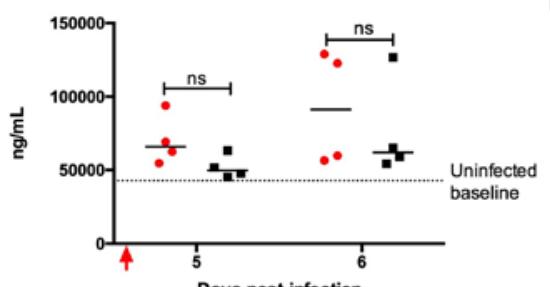

Days post-infection

- NS1-administered - OVA-administered
D
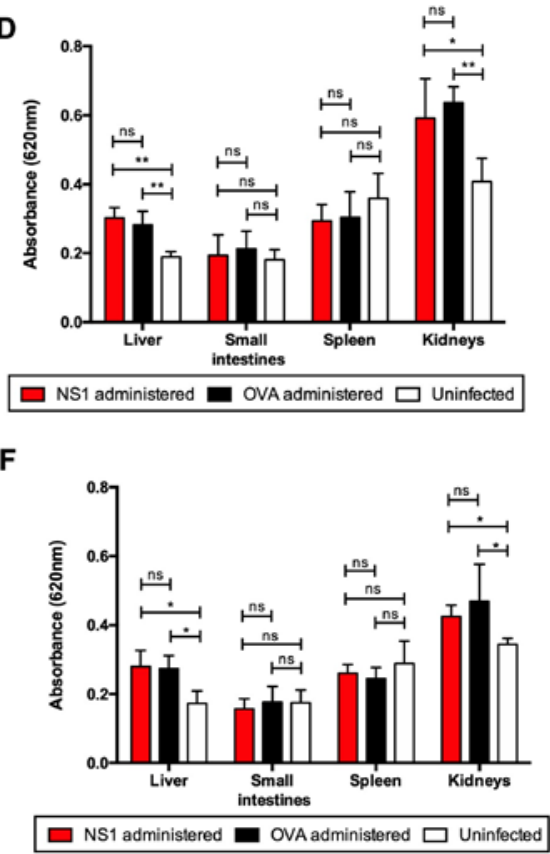

H

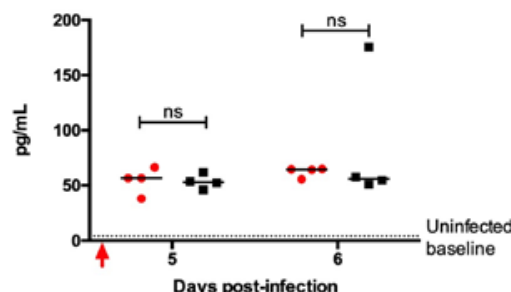

Days post-infection

- NS1-administered - OVA-administered

Fig. 5. Administration of NS1(D2Y98P) to AG129 mice infected with a sub-lethal dose of D2Y98P. (A) AG129 mice were sc challenged with $10^{3}$ PFU D2Y98P. At (B-D) day 2 p.i. or (E-H) day 4 p.i., infected mice were iv administered with $10 \mathrm{mg} / \mathrm{kg}$ NS1(D2Y98P) or OVA. (B, E) Systemic levels of sNS1 were measured at various time points p.i. $(n=4-5)$. Vascular leakage was evaluated in various tissues at (C) day 4 or (D, F) day 6 p.i. $(n=4-5)$. (G) Plasma heparan sulphate $(n=4)$ and $(H)$ TNF- $\alpha$ levels $(n=4)$ were measured at day 4 p.i. Data were analyzed by non-parametric Mann Whitney test. ${ }^{*} p<0.05$; ${ }^{* *} p<0.01$; ns: not significant. 

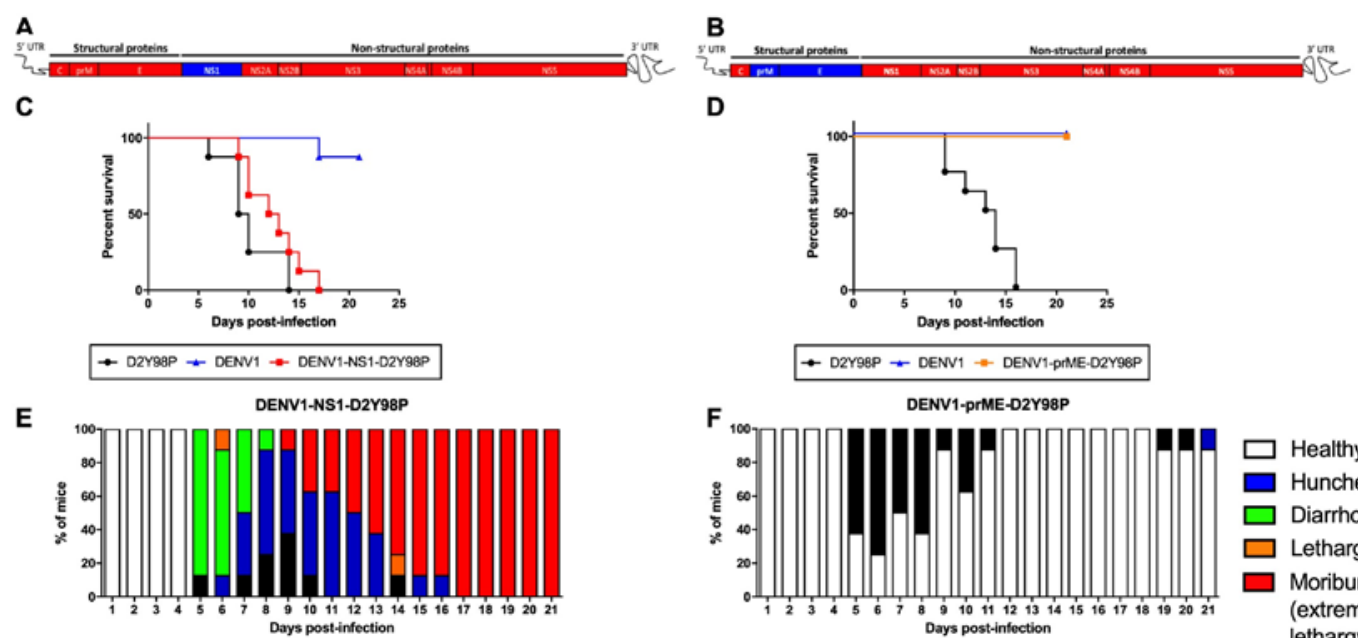

D
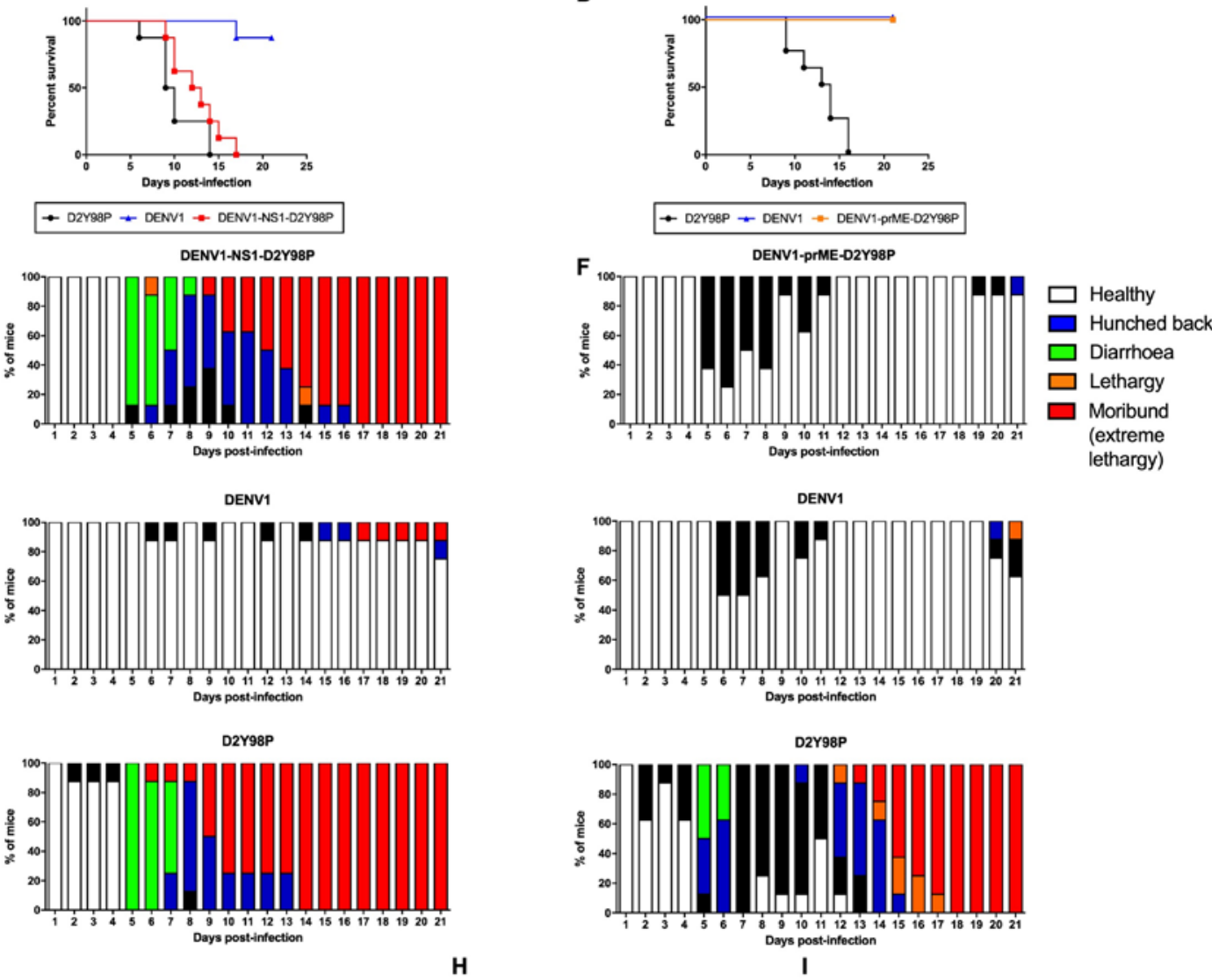

G

H
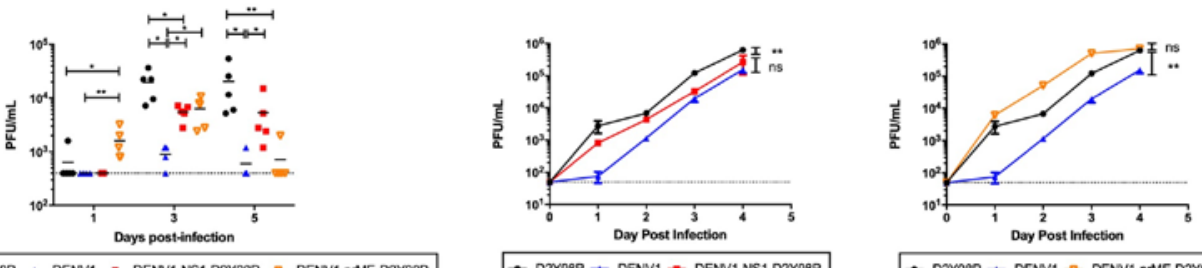

- D2Y98P A DENV1 - DEN1-NS1-D2Yg8P O DENY1-PME-DZYGBP

$\rightarrow$ D2Y9BP - DENV1 - DENV1-NS1-D2Y9BP
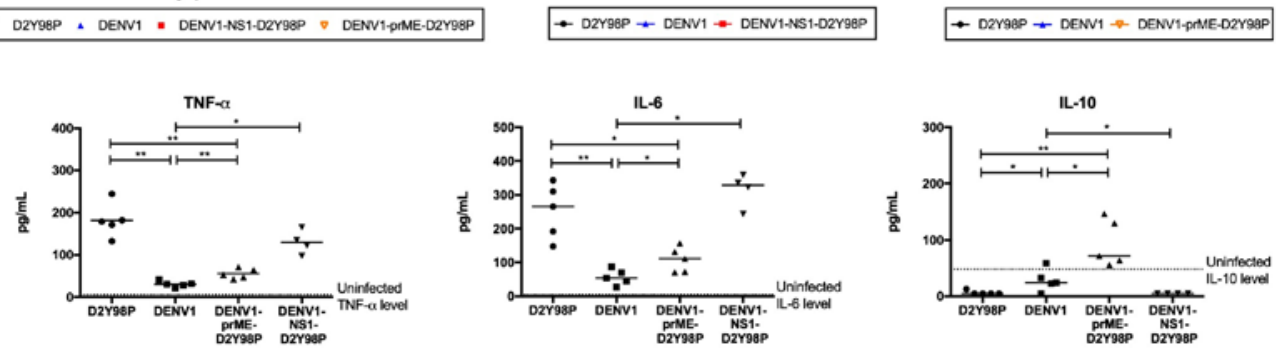

Fig. 6. In vivo and in vitro characterization of DENV1-NS1-D2Y98P and DENV1-prMED2Y98P chimeric viruses. (A) DENV1-NS1-D2Y98P or (B) DENV1-prME-D2Y98P chimeric strains consist of (A) NS1 or (B) prME coding region from DENV1 strain (blue) cloned into the backbone of D2Y98P strain (red). AG129 mice were sc infected with $10^{6} \mathrm{PFU}$ of D2Y98P, DENV1, DENV1-NS1-D2Y98P or DENV1-prME-D2Y98P. Mice $(\mathrm{n}=8)$ were monitored daily upon challenge. (C, D) The Kaplan-Meier survival curves and (E, F) clinical scores are shown. (G) Viremia titers were measured at day 1, 3 and 5 p.i. $(n=4)$. (H, I) In vitro virus titer in Vero cells infected with respective viruses. The viral kinetic curves were compared and analyzed by linear regression, which takes into consideration the slope and Y-intercept. (J) TNF- $\alpha$, IL-6 and IL-10 systemic levels were measured at day 5 p.i. $(n=4-5)$. Data between 
bioRxiv preprint doi: https://doi.org/10.1101/2020.02.01.929885; this version posted February $2,2020$. The copyright holder for this preprint (which was not certified by peer review) is the author/funder, who has granted bioRxiv a license to display the preprint in perpetuity. It is made available under aCC-BY-ND 4.0 International license.

WT and chimeric viruses were compared and analyzed by non-parametric Mann-Whitney test. ${ }^{*} p<0.05$; ${ }^{*} p<0.01$; ns: not significant. 


\section{Supplemental Information}

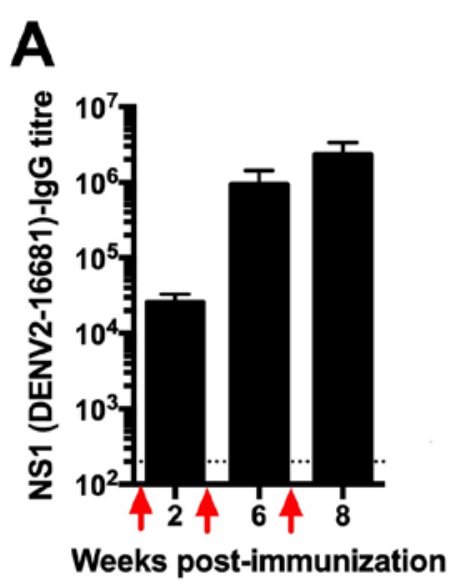

C

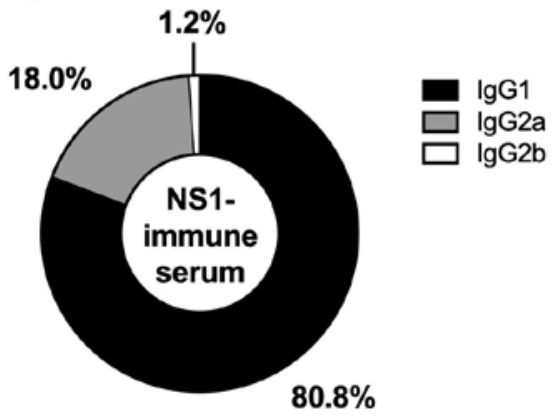

B

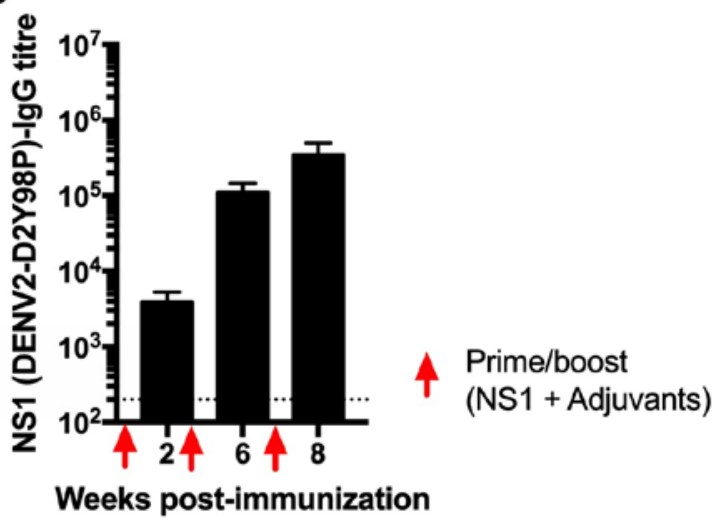

D

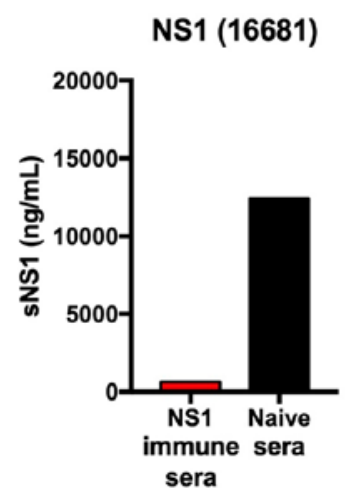

NS1 (D2Y98P)

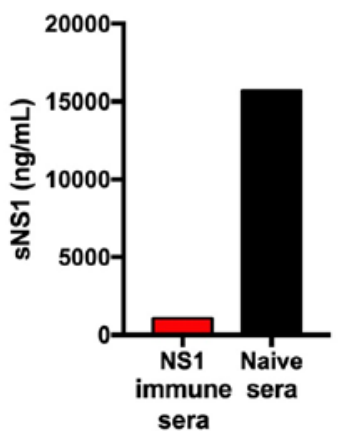

sera

Fig. S1. NS1-specific IgG titers in NS1 immune serum. A129 mice were ip immunized thrice with $20 \mu \mathrm{g}$ NS1(16681) or OVA adjuvanted with MPLA and Addavax at week two, six and eight. NS1-specific IgG antibody titers were measured by ELISA using NS1(16681) (A) or NS1(D2Y98P) (B) as coating antigen. Titers were calculated as the reciprocal of the highest serum dilution with absorbance corresponding to three times the absorbance of blank wells. The dotted line indicates the limit of detection. (C) The percentages of specific IgG subclasses were determined. (D) 5x-diluted NS1 immune serum was co-incubated with $20 \mu \mathrm{g} / \mathrm{mL}$ NS1(16681) or NS1(D2Y98) and the amount of free NS1 was measured by sandwich ELISA. 


\section{A}

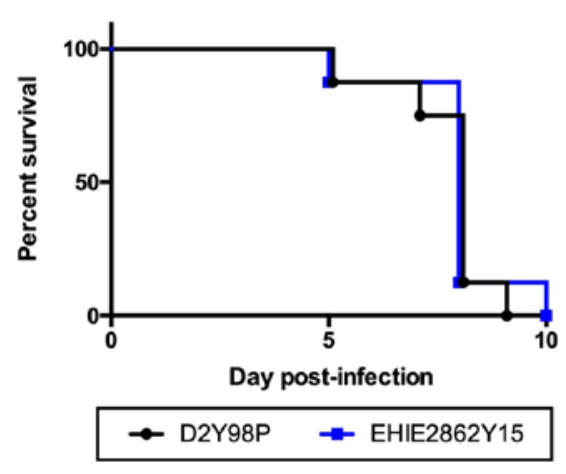

B EHIE2862Y15
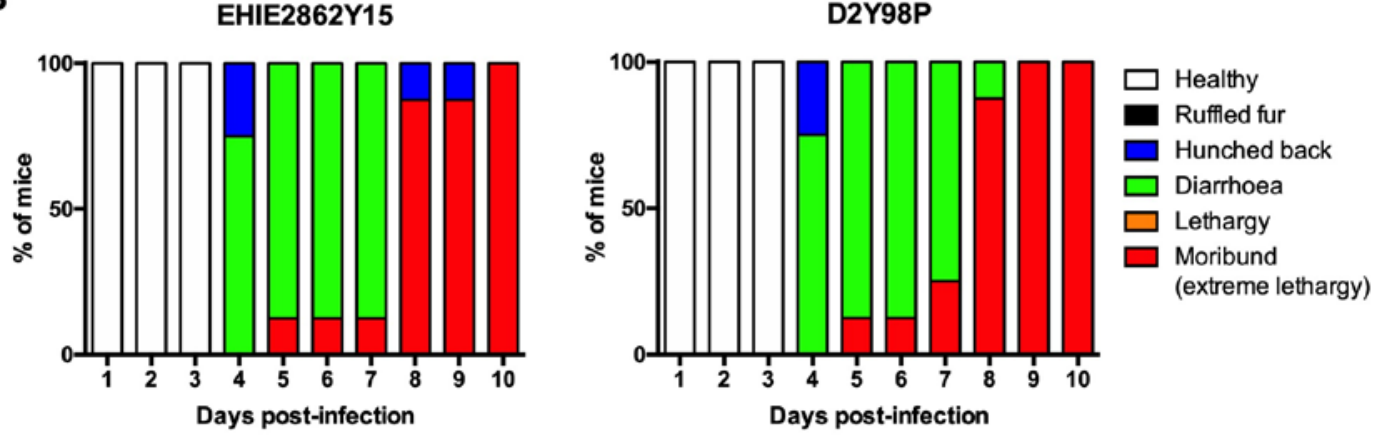

Fig. S2. In vivo fitness of EHIE2862Y15 strain in AG129 mice. AG129 mice (n = 8) were sc challenged with $10^{6} \mathrm{PFU}$ of EHIE2862Y15 or D2Y98P virus. Mice were monitored daily upon challenge. The Kaplan-Meier survival curve (A) and clinical scores (B) are shown. 


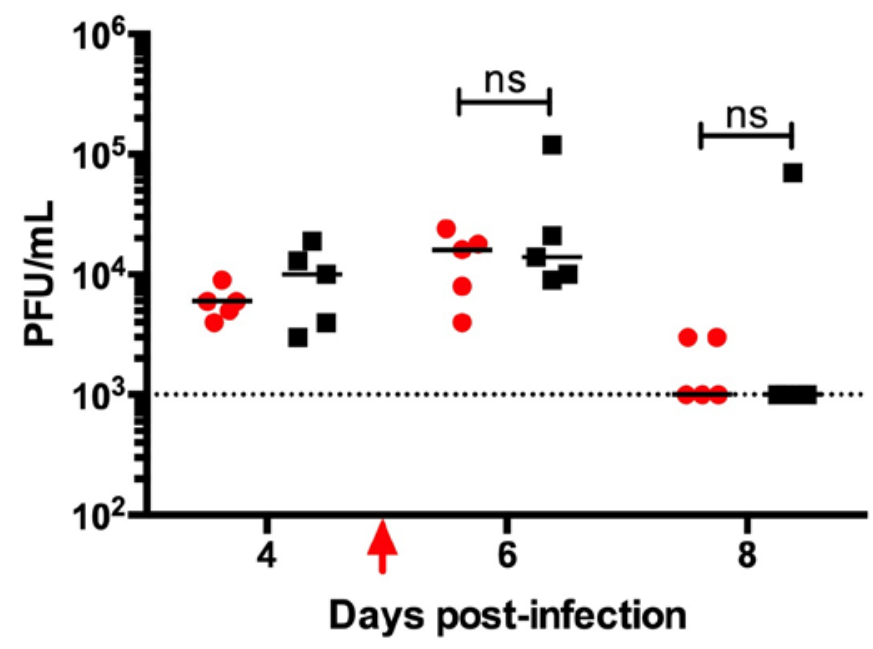

\section{- NS1-administered - OVA-administered}

个 Protein administered at day 4 post-infection

Fig. S3: Viremia titers in D2Y98P-infected AG129 mice administered with NS1. AG129 mice were sc challenged with $10^{3}$ PFU D2Y98P. At day 4 p.i., D2Y98P-infected mice were iv administered with $10 \mathrm{mg} / \mathrm{kg}$ NS1(16681) or OVA. Dotted line denotes the limit of detection. Data were analyzed by non-parametric Mann Whitney test. ns: not significant. 


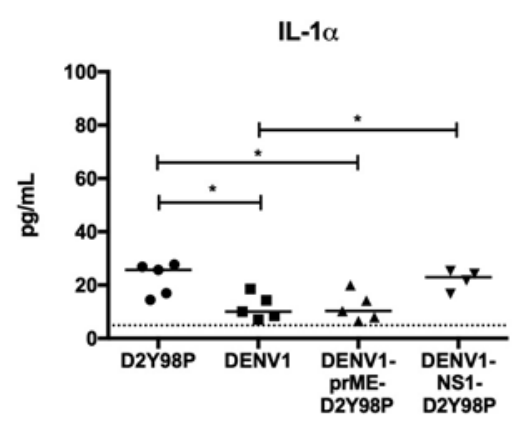

IL-12p70

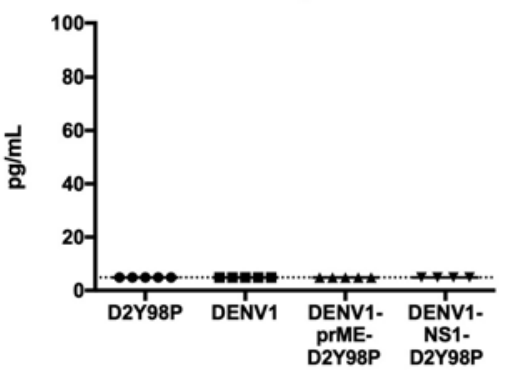

IL-23

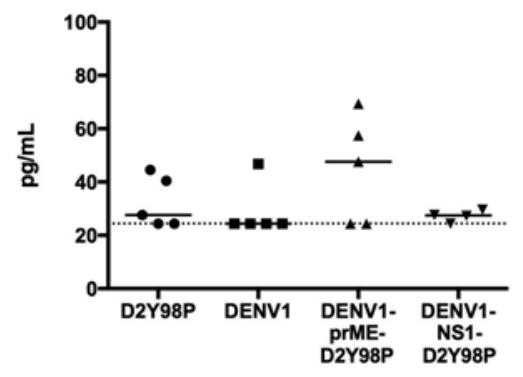

GM-CSF
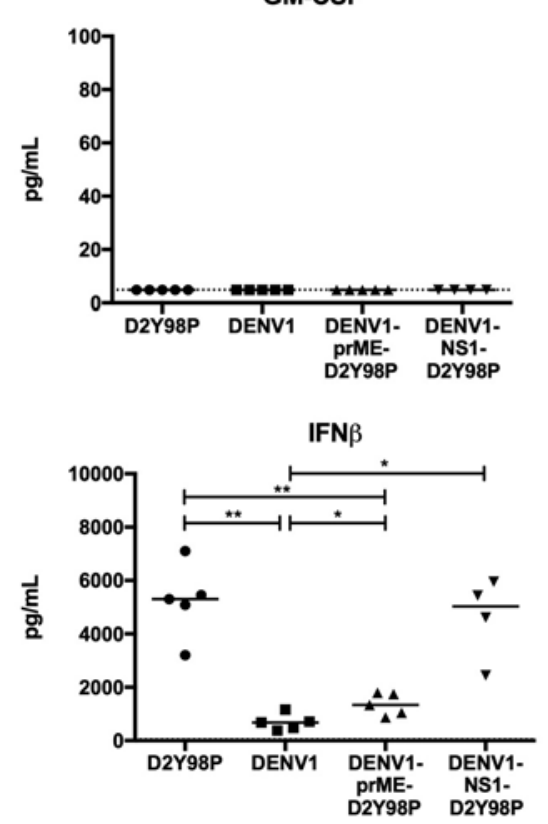

IL-1 $\beta$

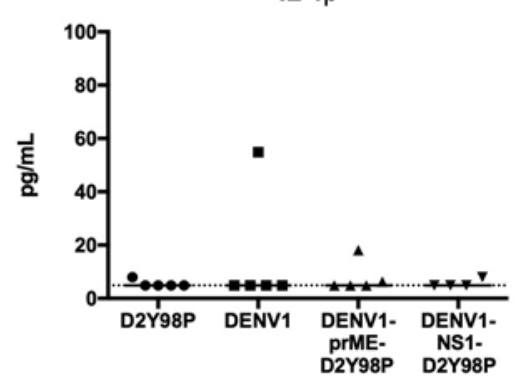

IL-17A

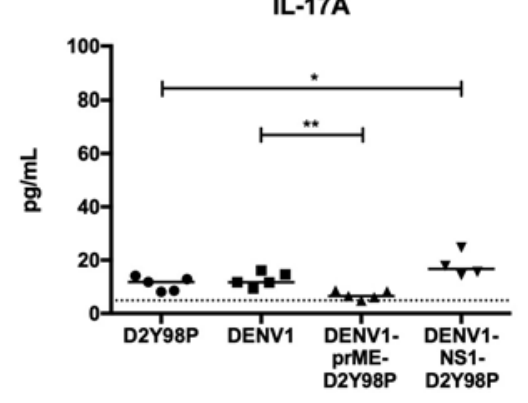

IL-27
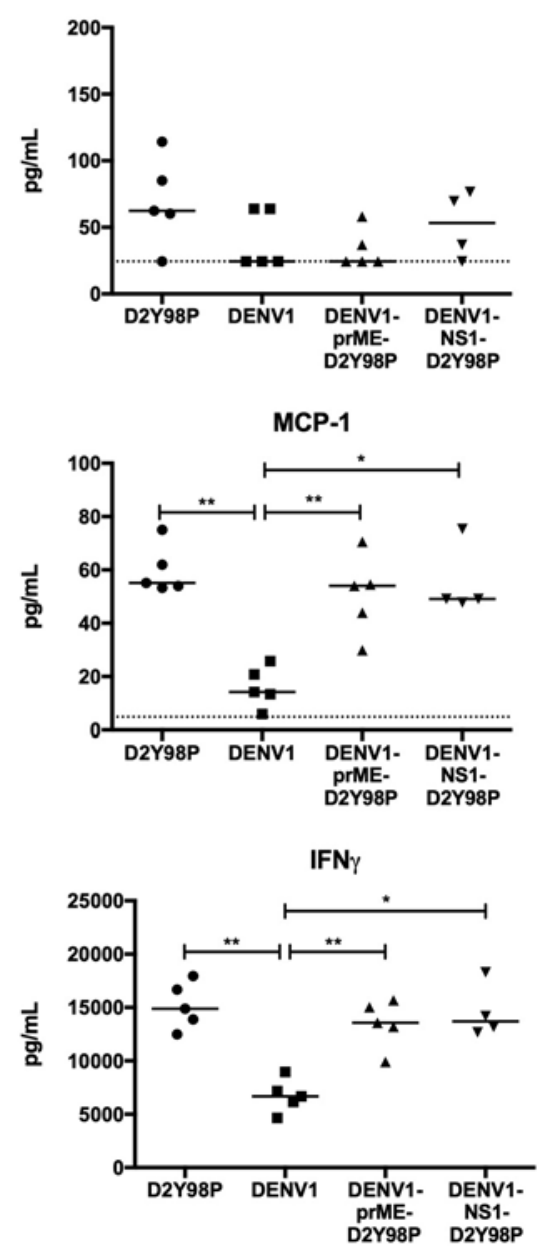

Fig. S4. Cytokine profile in AG129 mice infected with chimeric and parental viruses. AG129 mice $(n=4-5)$ were sc infected with $10^{6}$ PFU of D2Y98P, DENV1, DENV1-prME- 
bioRxiv preprint doi: https://doi.org/10.1101/2020.02.01.929885; this version posted February 2,2020 . The copyright holder for this preprint (which was not certified by peer review) is the author/funder, who has granted bioRxiv a license to display the preprint in perpetuity. It is made available under aCC-BY-ND 4.0 International license.

D2Y98P or DENV1-NS1-D2Y98P virus. At day 5 p.i., the systemic levels of various cytokines was measured. Data were analyzed by non-parametric Mann-Whitney test. ${ }^{*} p<0.05$; ${ }^{* *} p<0.05$. 
Table S1. Comparison of D2Y98P genome against DENV2 NGC strain and Singapore DENV2 clinical isolates.

\begin{tabular}{|c|c|c|c|c|c|c|}
\hline Strains & $\begin{array}{c}\text { Year } \\
\text { collected }\end{array}$ & Country & Identities & Gaps & $\begin{array}{c}\text { GenBank } \\
\text { accession } \\
\text { no. }\end{array}$ & Reference \\
\hline $\begin{array}{c}\text { DENV2 } \\
\text { New Guinea } \\
\text { C (NGC) }\end{array}$ & 1944 & $\begin{array}{c}\text { Papua New } \\
\text { Guinea }\end{array}$ & $\begin{array}{c}10100 / \\
10724 \\
(94 \%)\end{array}$ & $\begin{array}{c}2 / \\
10724 \\
(0 \%)\end{array}$ & $\begin{array}{c}\text { KM204118 } \\
.1\end{array}$ & $\begin{array}{c}\text { Anez et al. } \\
2016\end{array}$ \\
\hline $\begin{array}{c}\text { SG(EHI)D2 } \\
\text { /0411Y07 } \\
\text { (Only E } \\
\text { protein) } \\
\end{array}$ & 2007 & Singapore & $\begin{array}{c}1457 / \\
1485 \\
(98 \%)\end{array}$ & $\begin{array}{c}0 / 1485 \\
(0 \%)\end{array}$ & $\begin{array}{c}\text { JN030296. } \\
1\end{array}$ & $\begin{array}{l}\text { Lee et al., } \\
2012\end{array}$ \\
\hline $\begin{array}{c}\text { SGEHI(D2) } \\
\text { 0722Y07 } \\
\text { (CDS) }\end{array}$ & 2007 & Singapore & $\begin{array}{l}9978 / \\
10176 \\
(98 \%)\end{array}$ & $\begin{array}{c}0 / 1017 \\
6 \\
(0 \%)\end{array}$ & $\begin{array}{c}\text { JN851120. } \\
1\end{array}$ & $\begin{array}{c}\text { Lee et al., } \\
2012\end{array}$ \\
\hline $\begin{array}{c}\text { SG(EHI)D2 } \\
\text { /1036Y08 } \\
\text { (Only E } \\
\text { protein) }\end{array}$ & 2008 & Singapore & $\begin{array}{c}1454 / \\
1485 \\
(98 \%)\end{array}$ & $\begin{array}{c}0 / 1485 \\
(0 \%)\end{array}$ & $\begin{array}{c}\text { JN030321. } \\
1\end{array}$ & $\begin{array}{l}\text { Lee et al., } \\
2012\end{array}$ \\
\hline $\begin{array}{c}\text { SGEHI(D2) } \\
\text { 0950Y08 } \\
\text { (CDS) }\end{array}$ & 2008 & Singapore & $\begin{array}{l}9976 / \\
10176 \\
(98 \%) \\
\end{array}$ & $\begin{array}{c}0 / 1017 \\
6 \\
(0 \%)\end{array}$ & $\begin{array}{c}\text { JN851122. } \\
1\end{array}$ & $\begin{array}{l}\text { Lee et al., } \\
2012\end{array}$ \\
\hline $\begin{array}{c}\text { SG(EHI)D2 } \\
/ 10622 Y 09 \\
\text { (Only E } \\
\text { protein) }\end{array}$ & 2009 & Singapore & $\begin{array}{c}1453 / \\
1485 \\
(98 \%)\end{array}$ & $\begin{array}{c}0 / 1485 \\
(0 \%)\end{array}$ & $\begin{array}{c}\text { JN030290. } \\
1\end{array}$ & $\begin{array}{l}\text { Lee et al., } \\
2012\end{array}$ \\
\hline $\begin{array}{c}\text { SG(EHI)D2 } \\
\text { /77404Y10 } \\
\text { (Only E } \\
\text { protein) } \\
\end{array}$ & 2010 & Singapore & $\begin{array}{c}1452 / \\
1485 \\
(98 \%)\end{array}$ & $\begin{array}{c}0 / 1485 \\
(0 \%)\end{array}$ & $\begin{array}{c}\text { JN030320. } \\
1\end{array}$ & $\begin{array}{l}\text { Lee et al., } \\
2012\end{array}$ \\
\hline
\end{tabular}

CDS: Coding sequence. 
Table S2. Amino acid sequence comparison between EHIE2862Y15 and D2Y98P strains.

\begin{tabular}{|c|c|c|c|c|}
\hline $\begin{array}{l}\text { EHIE2862Y15 } \\
\text { vs D2Y98P }\end{array}$ & Identity & Positive & DENV Protein & Differences \\
\hline $\begin{array}{l}\text { Nucleotide } \\
\text { Level }\end{array}$ & $\begin{array}{l}10570 / 10723 \\
(98.6 \%)\end{array}$ & & & \\
\hline \multirow[t]{7}{*}{$\begin{array}{l}\text { Amino Acid } \\
\text { Level }\end{array}$} & \multirow[t]{7}{*}{$\begin{array}{l}3354 / 3368 \\
(99.6 \%)\end{array}$} & \multirow[t]{7}{*}{$\begin{array}{l}3359 / 3368 \\
(99.7 \%)\end{array}$} & NS1 & $\begin{array}{l}\text { T80S (+) } \\
\text { S178F }\end{array}$ \\
\hline & & & NS2A & $\begin{array}{l}\text { A171T } \\
\text { T189A }\end{array}$ \\
\hline & & & NS2B & $\begin{array}{l}\text { F21L } \\
\text { I59V }(+)\end{array}$ \\
\hline & & & NS3 & R15K (+) \\
\hline & & & NS4A & V89I (+) \\
\hline & & & NS4B & L52F \\
\hline & & & NS5 & $\begin{array}{l}\text { V271T } \\
\text { T414N } \\
\text { S585P } \\
\text { A637V } \\
\text { N676S (+) }\end{array}$ \\
\hline
\end{tabular}


Table S3. List of primers used for PCR amplification.

\begin{tabular}{|c|c|c|}
\hline \multicolumn{3}{|c|}{ Plasmid (pACYC177) amplification } \\
\hline \multirow[t]{2}{*}{ pACYC177 } & Forward & $\begin{array}{l}\text { TTGAATCAACAGGTTCTGGGTCGGCATGGCATC } \\
\text { TC }\end{array}$ \\
\hline & Reverse & $\begin{array}{l}\text { GTCCACGTAGACTAACTACTCTGACGGTTCACTA } \\
\text { AACCAGC }\end{array}$ \\
\hline \multicolumn{3}{|c|}{ Amplification of fragments from DENV2 D2Y98P strain } \\
\hline \multirow{3}{*}{$\begin{array}{l}\text { 5' UTR and } \\
\text { structural } \\
\text { regions }\end{array}$} & Forward & $\begin{array}{l}\text { CTGGTTTAGTGAACCGTCAGAGTAGTTAGTCTAC } \\
\text { GTGGAC }\end{array}$ \\
\hline & $\begin{array}{l}\text { Reverse } \\
\text { (Connect } \\
\text { to D220 } \\
\text { NS1) }\end{array}$ & $\begin{array}{l}\text { CTCACAACGCAACCACTATCGGCCTGCACCATA } \\
\text { ACTCC }\end{array}$ \\
\hline & $\begin{array}{l}\text { Reverse } \\
\text { (Connect } \\
\text { to } \\
\text { DENV1 } \\
\text { NS1) }\end{array}$ & $\begin{array}{l}\text { TTAATTACACATCCTGAATCGGCCTGCACCATAA } \\
\text { CTCC }\end{array}$ \\
\hline \multirow{3}{*}{$\begin{array}{l}\text { Non- } \\
\text { structural } \\
\text { fragment } 1 \\
\text { (without } \\
\text { NS1) }\end{array}$} & $\begin{array}{l}\text { Forward } \\
\text { (Connect } \\
\text { to D220 } \\
\text { NS1) }\end{array}$ & $\begin{array}{l}\text { CAACTCCTTGGTCACAGCCGGACATGGACAGAT } \\
\text { TGACAAC }\end{array}$ \\
\hline & $\begin{array}{l}\text { Forward } \\
\text { (Connect } \\
\text { to } \\
\text { DENV1 } \\
\text { NS1) } \\
\end{array}$ & $\begin{array}{l}\text { TCAAATCAATGGTCTCTGCAGGACATGGACAGA } \\
\text { TTGAC }\end{array}$ \\
\hline & Reverse & $\begin{array}{l}\text { ATTGCTGGAAGGTATCTCTTTGTTTTTCCTGCTC } \\
\text { C }\end{array}$ \\
\hline \multirow{2}{*}{$\begin{array}{l}\text { Non- } \\
\text { structural } \\
\text { fragment } 2\end{array}$} & Forward & $\begin{array}{l}\text { ACCCAGGAGCAGGAAAAACAAAGAGATACCTT } \\
\text { CCAGCAATAGTCAGAGAAG }\end{array}$ \\
\hline & Reverse & $\begin{array}{l}\text { TTTGAAGACGCACCAGATTCCAACCATATGTTG } \\
\text { ACATGG }\end{array}$ \\
\hline \multirow{2}{*}{$\begin{array}{l}\text { Non- } \\
\text { structural } \\
\text { fragment } 3\end{array}$} & Forward & $\begin{array}{l}\text { CCCATGTCAACATATGGTTGGAATCTGGTGCGTC } \\
\text { TTCAAAG }\end{array}$ \\
\hline & Reverse & $\begin{array}{l}\text { TGGAGATGCCATGCCGACCCAGAACCTGTTGAT } \\
\text { TCAAC }\end{array}$ \\
\hline \multicolumn{3}{|c|}{ Amplification of fragments from DENV1 (05K3903DK1) strain } \\
\hline \multirow[t]{2}{*}{ NS1 region } & Forward & $\begin{array}{l}\text { TGGGAGTTATGGTGCAGGCCGATTCAGGATGTG } \\
\text { TAATTAATTG }\end{array}$ \\
\hline & Reverse & $\begin{array}{l}\text { TTGTCAATCTGTCCATGTCCTGCAGAGACCATTG } \\
\text { ATTTG }\end{array}$ \\
\hline \multirow[t]{2}{*}{$\begin{array}{l}\text { prME } \\
\text { region }\end{array}$} & Forward & $\begin{array}{l}\text { TGATTCCAACAGTGATGGCGTTCCATTTGACTAC } \\
\text { ACGAGG }\end{array}$ \\
\hline & Reverse & $\begin{array}{l}\text { CTCACAACGCAACCACTATCCGCCTGAACCATG } \\
\text { ACTCC }\end{array}$ \\
\hline
\end{tabular}

